\title{
Heats of Solution, Transition, and Formation of Three Crystalline Forms of Metaboric Acid
}

\author{
Marthada V. Kilday and Edward J. Prosen
}

\begin{abstract}
(October 3, 1963)
The three crystalline forms of metaboric acid $\mathrm{HBO}_{2}$ were prepared, purified, and analyzed. Heats of solution in water or of reaction with sodium hydroxide solution were compared with those of orthoboric acid $\mathrm{H}_{3} \mathrm{BO}_{3}(\mathrm{c})$. The best values for the heats of transition at $25{ }^{\circ} \mathrm{C}$ are: $(\mathrm{c}, \mathrm{I})$ to $(\mathrm{c}, \mathrm{II}), 2.33 \pm 0.23 \mathrm{kcal} / \mathrm{mole}$; $(\mathrm{c}, \mathrm{II})$ to $(\mathrm{c}, \mathrm{III}), 1.30 \pm 0.05 \mathrm{kcal} / \mathrm{mole}$; $(\mathrm{c}, \mathrm{I})$ to $(\mathrm{c}, \mathrm{III}), 3.63 \pm 0.24 \mathrm{kcal} / \mathrm{mole}$. The following heats of formation at $25^{\circ} \mathrm{C}$ were derived: $-192.77 \pm 0.35 \mathrm{kcal} / \mathrm{mole}$ for the cubic $\mathrm{HBO}_{2}(\mathrm{c}, \mathrm{I}),-190.43 \pm 0.34 \mathrm{kcal} / \mathrm{mole}$ for the monoclinic $\mathrm{HBO}_{2}(\mathrm{c}, \mathrm{II})$, and $-189.13 \pm 0.34 \mathrm{kcal} / \mathrm{mole}$ for the orthorhombic $\mathrm{HBO}_{2}(\mathrm{c}, \mathrm{III})$.
\end{abstract}

\section{Introduction}

Three crystalline forms of metaboric acid $\mathrm{HBO}_{2}$ were identified and described by Kracek, Morey, and Merwin $[1]^{1}$ in 1938. The three forms are the cubic form $\mathrm{HBO}_{2}(\mathrm{c}, \mathrm{I})$, the monoclinic form $\mathrm{HBO}_{2}(\mathrm{c}, \mathrm{II})$, and the orthorhombic form $\mathrm{HBO}_{2}(\mathrm{c}, \mathrm{III})$. Although heat-of-solution data $[2-6]$ and other thermodynamic data are available on the monoclinic and orthorhombic forms, no heat of solution or formation data and little other thermodynamic information other than that of Kracek, Morey, and Merwin are available on the most stable form, the cubic. (See, however, the preliminary report of part of the present work [7].) An investigation [18] of the equilibrium decomposition pressures of orthoboric acid into water vapor and each of the three metaboric acids yielded both heat-of-formation [(c,I), - 192.6; (c,II), - 190.6; $(c, I I I),-189.0 \mathrm{kcal} / \mathrm{mole}]$ and entropy values for each of the forms. However, since the uncertainty in the heat of formation derived from those measurements was large, it was desirable to determine the heats of formation (or differences in heat of formation) by a more direct means.

The three crystalline forms of metaboric acid were prepared, purified, and analyzed. Heats of hydrolysis in water and heats of neutralization in sodium hydroxide solution were measured and compared with similar heats using orthoboric acid. From these heats of solution or neutralization, heats of transition and formation of the three forms of metaboric acid may be derived, since, as indicated by the work of Hibben [8], $\mathrm{H}_{3} \mathrm{BO}_{3}$ and $\mathrm{HBO}_{2}$ form the same final products in solution.

\section{Preparation and Analyses of Samples}

The experiences of Kracek [1] and Tazaki [9] as well as other thermodynamic and mechanism studies [18] of the decomposition pressures of orthoboric acid were considered in the development of the methods of preparation of the metaboric acid samples described in this paper.

Figures in brackets indicate the literature references at the end of this paper.
In general the samples were identified by X-ray diffraction, ${ }^{2}$ refractive index, ${ }^{3}$ and density measurements which were in agreement with the work of Kracek [1] and Tazaki [9]. The boron content of the various materials was determined from titrations (in the presence of an excess of D-mannitol) of aqueous solutions of weighed samples using $0.1 \mathrm{~N}$ sodium hydroxide and a Beckman $p \mathrm{H}$ meter with a glass electrode and a calomel reference electrode.

Quick identification and separation of the various crystals were made by flotation in the liquids listed in table 1 which also lists the densities of the metaboric acids and orthoboric acid.

TABLE 1. Densities of boric and metaboric acid crystals, and liquids used for flotation

\begin{tabular}{c|r}
\hline \hline \multicolumn{1}{c|}{ Substance } & Density \\
\cline { 2 - 2 } & \multicolumn{1}{c}{$g / \mathrm{cm}^{3}$} \\
$\mathrm{H}_{3} \mathrm{BO}_{3}(\mathrm{c})$ & 1.44 \\
Carbon tetrachloride & 1.60 \\
$\mathrm{HBO}_{2}(\mathrm{c}, \mathrm{III})$ & 1.78 \\
Ethyl $\mathrm{Iodide}_{\text {Hide }}$ & 1.92 \\
$\mathrm{HBO}_{2}(\mathrm{c}, \mathrm{II})$ & 2.04 \\
Ethylene bromide & 2.17 \\
$\mathrm{HBO}_{2}(\mathrm{c}, \mathrm{I})$ & 2.49 \\
& \\
\hline
\end{tabular}

For the sake of brevity in this paper $\mathrm{HBO}_{2}(\mathrm{c}, \mathrm{I})$, $\mathrm{HBO}_{2}(\mathrm{c}, \mathrm{II})$, and $\mathrm{HBO}_{2}(\mathrm{c}, \mathrm{III})$ will sometimes be referred to as (c,I), (c,II), and (c,III), respectively.

\section{1. $\mathrm{H}_{3} \mathrm{BO}_{3}(\mathrm{c})$}

Orthoboric acid, analytical grade reagent, was recrystallized three times from aqueous solution and air-dried at room temperature. It was stored in a desiccator containing a saturated solution of calcium bromide which maintains a relative humidity of about 20 percent at room temperature. A spectroscopic analysis ${ }^{4}$ of a sample prepared in this manner indicated a total impurity of not more than 0.001 mole percent. Titration analyses of the

\footnotetext{
${ }^{2}$ A. Perloff of the Constitution and Microstructure Section of the Minera Products Division.

${ }^{3}$ C. P. Saylor of the Pure Substances Section of the Analytical and Inorganic 4 Spectrochemistry Section of the Analytical and Inorganic Chemistry Division.
} 

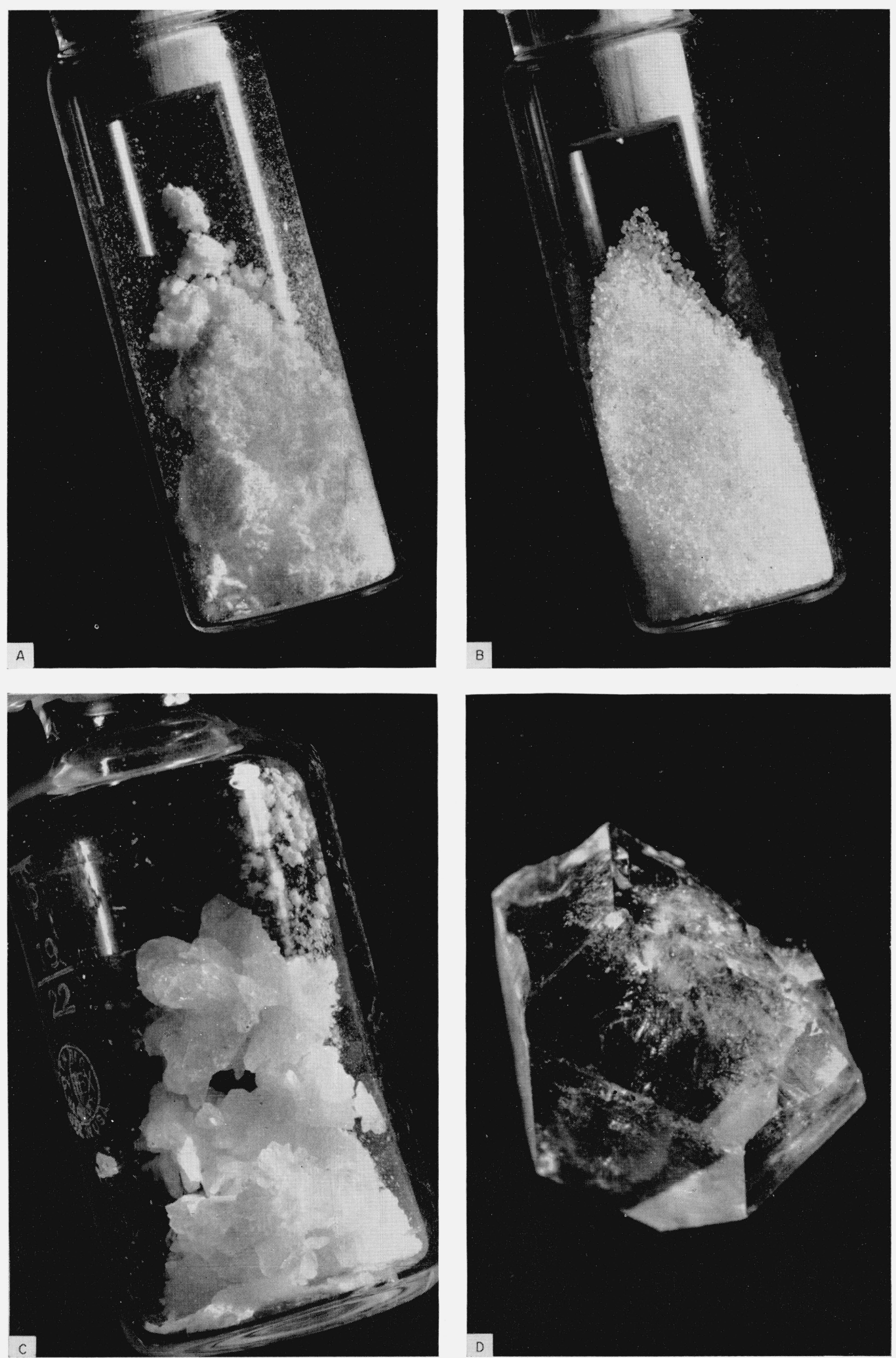

FIGURE 1. The various crystal forms of metaboric acid:

A. orthorhombic, B. cubic, $\dot{C}$. monoclinic, and D. a large single cyrstal of the cubic $\mathrm{HBO}_{2}(\mathrm{c}, \mathrm{I})$, actual size, approximately $3.5 \mathrm{~mm} ; A, B$, and $C$ are approximately actual size. 
final calorimetric solutions of boric acids in water indicated a weight of boric acid averaging 99.72 \pm $0.09(\mathrm{sdm})$ percent of the sample weight; the accuracy of the titration analyses was estimated to be a few tenths of a percent the total boric acid.

\section{2. $\mathrm{HBO}_{2}(\mathrm{c}, \mathrm{III})$}

It should be possible in preparing the metaboric acids from orthoboric acid to choose conditions of temperature, pressure, and humidity which would result in pure products if the conditions were accurately controlled. However, the preparations described here contained mixtures of the metaboric acids and orthoboric acid which were separated by flotation methods and/or analyzed to determine the composition of the sample.

The orthorhombic form of metaboric acid was obtained by dehydration of orthoboric acid in open Petri dishes at $65{ }^{\circ} \mathrm{C}$ and the samples were weighed every 2 or 3 days during the dehydration. The relative humidity of the atmosphere generally ranged from 15 to 30 percent but occasionally for brief periods it was as high as 55 percent. The theoretical weight for metaboric acid was reached in 1 to 3 weeks, however, this was not an exact indication of the completeness of dehydration since orthoboric acid volatilizes to an appreciable extent at $65{ }^{\circ} \mathrm{C}$. At this temperature and humidity the only impurity expected and found in the product was orthoboric acid, the amount of which varied somewhat with the atmospheric conditions during preparation. The products generally contained 80 to 90 percent (c, III). The samples were stored in glass-stoppered bottles over anhydrous magnesium perchlorate drying agent, and subsequent manipulations were performed in a dry box. The appearance of the product may be seen in figure 1a.

\section{3. $\mathrm{HBO}_{2}(\mathrm{c}, \mathrm{II})$}

The monoclinic form of metaboric acid was prepared at $120{ }^{\circ} \mathrm{C}$ by dehydration of wet orthoboric acid in bottles with loose-fitting glass stoppers to impede the escape of water vapor. The dehydration generally required 3 to 4 weeks. Extended heating was not desirable because greater contamination with (c,I) developed. Formation of $(c, I I)$ was apparent from the presence of globules or treelike structures. The best yield of the (c,II) was obtained when the starting material was orthoboric acid which had not been thoroughly dried but was still moist with the liquid from recrystallization.

These preparations contained the three crystal forms of metaboric acid as well as some orthoboric acid. The purification and all subsequent manipulations of the $(c, I I)$ were performed in a dry box to prevent the sample from reacting with atmospheric moisture. The product was first washed thoroughly with spectroscopic-grade $\left(\mathrm{H}_{2} \mathrm{O}\right.$-free) carbon tetrachloride to remove $\mathrm{H}_{3} \mathrm{BO}_{3}$ (c) and (c,III) by flotation and solution. Figure $1 \mathrm{c}$ shows the material at this stage of the purification. The remaining clusters of crystals were crushed (but not ground) in a mortar. When they were added to ethyl iodide (analytical reagent), the (c,II) and (c,I) sank to the bottom. The floating crystals and the ethyl iodide were removed before adding ethylene bromide in which (c,II) floats but (c,I) does not. The floating crystals, mostly needlelike in form were removed, washed with $\mathrm{H}_{2} \mathrm{O}$-free $\mathrm{CCl}_{4}$, and dried at $120{ }^{\circ} \mathrm{C}$ for about 30 min before storing in a glass-stoppered bottle over anhydrous magnesium perchlorate.

Flotation did not completely separate (c,I) from $(c, I I)$ due to air-bubble effects and to inclusion of (c,I) by (c,II). However, (c,II) dissolves moderately rapidly in water at $25^{\circ} \mathrm{C}$ while $(c, I)$ is only very slightly soluble at that temperature, thus it was possible to determine the amount of $(c, I I)$ by titration of an aqueous solution of the sample. About 1 percent of $(c, I)$ was found in the best samples; details will be given in the analyses of the calorimetric solutions.

\section{4. $\mathrm{HBO}_{2}(\mathrm{c}, \mathrm{I})$}

The most stable form of metaboric acid, the cubic $\mathrm{HBO}_{2}(\mathrm{c}, \mathrm{I})$, has been prepared by several methods. One method was similar to the preparation of $(c, I I)$ except that the orthoboric acid was not wet initially and a period of 4 to 5 waeks was required to complete the dehydration. This product consisted of crystals of $(\mathrm{c}, \mathrm{I})$ approximately $1 \mathrm{~mm}$ in size mixed with some $(c, I I)$. Figure $1 b$ shows this product after purification.

Another method of preparing the $(c, I)$ resulted in a product which contained essentially no impurities. Thin glass spherical bulbs, $1.5 \mathrm{~cm}$ diam, were blown at the end of $4 \mathrm{~mm}$ (o.d.) glass tubing; the overall length was approximately $12 \mathrm{~cm}$. The bulbs were filled with orthoboric acid and weighed. After heating at $110{ }^{\circ} \mathrm{C}$ for approximately 4 weeks the samples had reached constant weight at approximately that of metaboric acid.

A third method produced crystals which were generally smaller than those formed in the other two methods, but occasionally larger crystals were formed; the largest single crystal obtained was approximately $3.5 \mathrm{~mm}$ in size and is shown in figure $1 \mathrm{~d}$. In this method $5 \mathrm{~g}$ of orthoboric acid, $15 \mathrm{~g}$ of (c,III), and a few seed crystals of $(c, I)$ were sealed, after brief evacuation, in a $100-\mathrm{ml}$ Pyrex-glass ampoule and heated at $180^{\circ} \mathrm{C}$. Sometimes in a day or two, the melt developed "cloudiness" indicating crystal formation, but at other times it was as much as a week before crystallization was visible; 2 to 5 weeks was allowed for crystal aggregation but this was no guarantee of large crystal formation. As the ampoule cooled, the mixture formed a solid mass which adhered tightly to the surface of the glass but apparently did not attack the glass, because it was possible after soaking with water to scrape off the crystals leaving a smooth glass surface.

Samples of $(c, I)$ of high purity were obtained by washing the products of the above preparations with water since the cubic form is only very slightly soluble. The cubic crystal surfaces were attacked 
after several hours exposure to water at room temperature, but extended washing with methanol effectively dissolved the other forms of $\mathrm{HBO}_{2}$ and did not mar the crystal surfaces. We feel that a sample of high purity was obtained in this way although it was not possible to obtain a quantitative analysis with respect to the crystal form. When weighed samples were dissolved in boiling water and titrated in the presence of excess D-mannitol, $99.89 \pm$ 0.03 percent of the theoretical amount of boric acid was found in the analyses of four samples.

\section{Apparatus and Procedures}

\subsection{Calorimetric Apparatus and Procedures}

The calorimeter employed in these experiments is shown in figure 2 and described in [10]. The

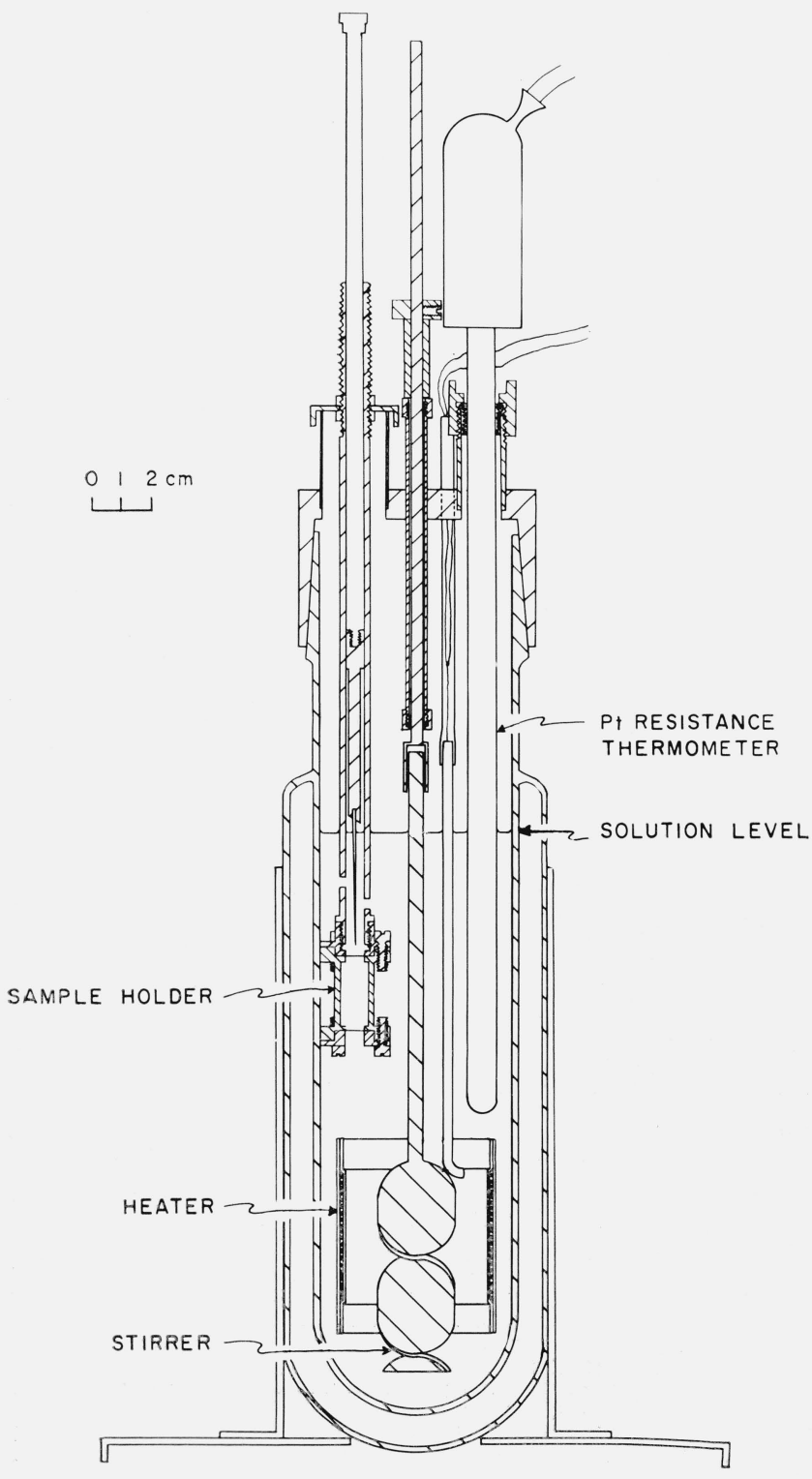

FIgURE 2. The solution calorimeter. temperature of the water bath was maintained at approximately $25{ }^{\circ} \mathrm{C}$ or $40{ }^{\circ} \mathrm{C}$ and normally varied by $\pm 0.003{ }^{\circ} \mathrm{C}$ during an experiment. The bath, temperature controls, and method and instruments for measuring time, temperature, and electrical energy have been described previously $[10,11,12]$.

Each calorimetric experiment included a preliminary equilibration period of 20 to $30 \mathrm{~min}$, a 20-min initial rating period, an electrical calibration period, a 20-min middle rating period, a chemical reaction period, and a 20 -min final rating period. The temperature was recorded at 2 -min intervals during the rating periods, and at 1 -min intervals during the calibration and chemical reaction periods. The electrical calibration period lasted either $20 \mathrm{~min}$ with 7 or $9 \mathrm{~min}$ of heating or $10 \mathrm{~min}$ with $5 \mathrm{~min}$ of heating; temperature rises were 0.01 ohm per minute of heating. The chemical reaction periods generally made $40 \mathrm{~min}$ long for the solution in water and 20 or 30 min long for the solution in sodium hydroxide to insure complete solution.

In early experiments glass bulbs were used to contain the samples with a holder similar to that described in [12]. In later experiments the Monel capsule shown in figure 2 was used and platinum disks, 1 mil thick, closed the ends of the sample holder. The stirring rate in early experiments was $500 \mathrm{rpm}$ but was later increased to $1000 \mathrm{rpm}$ in order to prevent the $(\mathrm{c}, \mathrm{I})$ from settling to the bottom, and to dissolve the samples within a reasonable length of time for calorimetric measurements.

Three series of calorimetric experiments to be reported differ somewhat in procedure and in the composition of the calorimetric systems.

Series $I$-In the earlier experiments, the samples were contained in glass bulbs and the stirring rate of $500 \mathrm{rpm}$ was used. The heats of solution in water were measured using $500 \mathrm{~g}$ (27.8 moles) of water in the calorimeter. For measuring the heat of reaction in $2 N$ sodium hydroxide solution, the calorimetric solution was prepared in the calorimeter by adding $135 \mathrm{~g}$ of a stock solution of $10 \mathrm{~N}$ sodium hydroxide to $402 \mathrm{~g}$ (22.3 moles) of water. In this series, heats of solution in water and in $2 N$ sodium hydroxide were measured at $25{ }^{\circ} \mathrm{C}$ ior orthoboric acid and metaboric acid (c,II), and heats of solution in $2 N$ sodium hydroxide were measured at $40{ }^{\circ} \mathrm{C}$ for orthoboric acid and metaboric acids (c, II) and (c,I).

The process of filling the thin glass bulbs with the samples of the metaboric acids was a tedious and time-consuming one, and the evacuation and sealing of the bulbs after filling introduced the possibility of decomposition of the samples. These difficulties were eliminated in later experiments where the Monel capsule replaced the glass bulb as the sample container. The containers for the metaboric acids were always filled in a dry box but those for orthoboric acid were filled in the room atmosphere.

Series $I I$-These experiments were similar to those of Series III except that the samples were enclosed in glass bulbs rather than in the Monel capsule. 
Series III-In these experiments, using the Monel capsule and the 1000 -rpm stirring rate, the heat capacity of the system was reduced. For the heats of solution in water the calorimeter contained $452 \mathrm{~g}$ (25 moles) of water. For the heats of reaction in $2 N$ sodium hydroxide the calorimeter contained 362 $\mathrm{g}$ (20 moles) of water plus $122 \mathrm{~g}$ of the stock solution of $10 \mathrm{~N}$ sodium hydroxide. In this series heats of solution in water were measured at $25{ }^{\circ} \mathrm{C}$ for orthoboric acid, metaboric acids (c,III) and (c,II); and heats of reaction in $2 N$ sodium hydroxide at $25{ }^{\circ} \mathrm{O}$ were measured for orthoboric acid, metaboric acids (c,III), (c,II), and (c,I).

The cubic $\mathrm{HBO}_{2}(\mathrm{c}, \mathrm{I})$ is the most stable form of metaboric acid and the solution in which the $(c, I)$ dissolved completely within a reasonable length of time and under conditions suitable for calorimetric measurements was also used for measurements of the heats of solution of the two less stable forms of metaboric acid and of orthoboric acid. Solution of $(\mathrm{c}, \mathrm{I})$ was accomplished in a $2 N$ sodium hydroxide solution at $40{ }^{\circ} \mathrm{C}$ in approximately $30 \mathrm{~min}$ at a stirring rate of $500 \mathrm{rpm}$ when the sample was crushed to pass a No. 200 standard sieve. The crushing and sieving of the sample was a tedious operation which was performed in the room atmosphere; the gain in weight resulting from reaction with and/or adsorption of moisture from the atmosphere amounted to less than 1 percent of the sample weight. No difference was detected by X-ray analysis between the sieved and the uncrushed samples.

In preparing the calorimetric samples of $(\mathrm{c}, \mathrm{I})$, the freshly sieved material was heated at $120^{\circ} \mathrm{C}$ for 1 hr and cooled in a desiccator. Thin glass bulbs were filled with the sample in a dry box; the bulbs were then removed from the dry box, attached to a vacuum manifold, and sealed off under reduced pressure. These samples were used for solution in sodium hydroxide at $40{ }^{\circ} \mathrm{C}$. It was later learned that the sample could also be dissolved at $25^{\circ} \mathrm{C}$ in approximately $50 \mathrm{~min}$ by doubling the stirring rate. In the two experiments under these conditions the Monel capsule was used as the sample container rather than the glass bulbs; the capsule was filled in a dry box.

\subsection{Determination of Energy for Initiating Reactions}

The energy for breaking the glass bulbs was too small to be measured in this system; the limit of detection was about $0.4 \mathrm{j}$. Other investigators [14] have measured the energy and found that $0.2 \mathrm{j}$ or less was required to break thin glass bulbs. When the Monel capsule was used to contain the sample, the energy required to break the two platinum disks was affected by several factors other than the properties of the disks, namely, the reaction rate, the particle size, and the extent to which the capsule was filled. Thus there was a large percentage of uncertainty in the determination of this energy.

The disk-breaking energy was determined as follows. In two experiments where the capsule contained only water the energy for breaking the the disks was found to be approximately $1.5 \mathrm{j} /$ expt.; this was near the limit of detection in this calorimeter, and not typical of the energies involved in the metaboric acid experiments because there was no friction resulting from the presence of crystalline samples. It was believed that disk-breaking energies more comparable to those of the experiments reported later in this paper were obtained in three series of experiments in which the heats of solution in water at $25^{\circ} \mathrm{C}$ were measured for $\mathrm{NaCl}$ and $\mathrm{KCl}$. The disk-breaking energy was obtained from the difference between the measured energy and the theoretical energy calculated from the weight of sample, using the following heats of solution: 1.001 $\mathrm{kcal} / \mathrm{mole}$ for $\mathrm{NaCl}$ (dilution $=1000 \mathrm{H}_{2} \mathrm{O}$ ) [15] and $4.187 \mathrm{kcal} / \mathrm{mole}$ for $\mathrm{KCl}$ (dilution $=1500 \mathrm{H}_{2} \mathrm{O}$ ) [15]. The average disk-breaking energies obtained were, respectively, $3.86 \pm 0.24(\mathrm{sdm}) \mathrm{j} / \mathrm{expt}$. and $9.84 \pm 1.01$ (sdm) j/expt. The mean of these values, $7 \pm 4$ j/expt., was used to correct the experiments of series III.

\subsection{Thermal Equilibrium}

A disadvantage in the use of a glass, vacuumjacketed calorimeter is that thermal equilibrium is reached slowly between the constant-temperature bath, the glass walls of the calorimeter, and the calorimeter solution after a change in the temperature of the calorimeter solution. In order to determine the magnitude of errors resulting from failure to acheive thermal equilibrium in both exothermic and endothermic reactions, an experiment was performed which involved no chemical energy. An increase in temperature was produced by electrical heating; a decrease, by inserting a copper rod precooled in liquid nitrogen into a copper tube which extended into the calorimeter solution and withdrawing the rod when the desired temperature drop was acheived. A 2-hr equilibration period was followed by a 50-min initial rating period, a 10-min heating period, which included $5 \mathrm{~min}$ of electrical heating, a 60-min middle rating period, a $10-\mathrm{min}$ cooling period during which the copper rod was inserted for $1 \frac{1}{2} \mathrm{~min}$, and a $60-\mathrm{min}$ final rating period. The results indicated that equilibrium was not reached until at least 45 min after the cessation of electrical heating or withdrawal of the cold rod. It was estimated that an error of 0.5 percent for a temperature rise of 0.05 $\mathrm{ohm}$ resulted from using reaction periods of only 10 or $20 \mathrm{~min}$ (as in the calibrations), and an error of 1.0 percent for a temperature drop of $0.02 \mathrm{ohm}$. For the experiments reported in this paper, the largest errors (1 to 2 percent of the total energy absorbed by the system) occurred in the aqueous solutions which were endothermic. The errors in the exothermic reactions (solutions in sodium hydroxide) were about 0.5 percent or less. Although these errors were considered in the overall uncertainties, they tend to cancel in the calculation of the heats of formation and transition.

\subsection{Chemical Analyses and Procedure}

The actual composition in terms of species of the final calorimetric solutions was not determined. 
However, Hibben [8] found from infrared and Raman measurements on aqueous solutions of boric acid and borates that only $\mathrm{H}_{3} \mathrm{BO}_{3}$ and $\mathrm{BO}_{2}{ }^{-}$are present in dilute solutions. Thus, when ortho- or metaboric acid is dissolved in water, $\mathrm{H}_{3} \mathrm{BO}_{3}(\mathrm{aq})$ is the product; and, when dissolved in aqueous bases, the metaborate ion is formed. By assuming that the products of solution are the same for orthoboric acid and for the three metaboric acids, the heat of formation for any of the metaboric acids can be calculated knowing only the heat of solution of orthoboric acid and of the metaboric acid, and the heats of formation of water and of orthoboric acid.

The final calorimetric solutions in water were analyzed by titration for orthoboric acid, but it was not possible to obtain an accurate analysis of the solutions in the sodium hydroxide. Therefore, these heats of reaction are based on the number of moles calculated from the sample weight and the average composition of the samples obtained from analyses of the aqueous solutions. The final calorimetric solution from the water experiments was diluted to $500 \mathrm{ml}$ or $1000 \mathrm{ml}$ and appropriate aliquots were taken for titration in the presence of excess Dmannitol with a standard $0.1 N$ sodium hydroxide solution. A Beckman $p \mathrm{H}$ meter was used to indicate the end points which occurred at about $p H$ 7.8. These titrations are probably accurate to a few tenths of a percent. The ratio of the amount of boric acid found in the titrations to the amount of boric acid based on the sample weight is an indication of the purity of the sample with respect to chemical composition but not to crystal form. From the boric acid ratio it was possible to calculate the amount of orthoboric acid present in the samples of $\mathrm{HBO}_{2}(\mathrm{c}, \mathrm{III})$, and the average composition of these samples was applied in corrections calculated for the solutions of the same sample in sodium hydroxide where it was not possible to obtain an accurate analysis of the final calorimetric solutions.

The final calorimetric solutions of the samples of metaboric acid $(c, I I)$ in water contained the undissolved $(c, I)$. Therefore, the final solution was filtered through a coarse filter paper and the filtrate was titrated as described above; the number of moles of boric acid found in this titration was assumed to be equal to the number of moles of (c,II) in the sample. the difference between this and the number of moles of metaboric acid in the sample as calculated from its weight, was taken as the amount of $(c, I)$ in the sample. An approximate check on this value was obtained from titration of an aqueous solution of the undissolved residue. This value was not as accurate as that obtained from the weight of sample because the amount of $(\mathrm{c}, \mathrm{I})$ was only about 1 to 5 percent of the sample, and losses during the manipulations of such small crystals were likely to occur.

The approximate amount of $(c, I)$ which dissolved in water at $25^{\circ} \mathrm{C}$ was determined by adding a weighed sample of $(\mathrm{c}, \mathrm{I})$ to $452 \mathrm{ml}$ of distilled water in the calorimeter and stirring at about $1000 \mathrm{rpm}$ for $2 \mathrm{hr}$. The solution was then filtered through a fine filter paper and the filtrate was titrated for boric acid. As would be expected, more rapid solution occurred when the samples were of small particle size. Approximately $9 \mathrm{mg}$ dissolved from a $0.3-\mathrm{g}^{\circ}$ sample which was 40-70 mesh, $15 \mathrm{mg}$ dissolved from a similar sample which was less than 100 mesh, and 2 $\mathrm{mg}$ dissolved from a $0.030 \mathrm{~g}$ sample (<100 mesh). The time during which the samples were exposed to the water in these experiments was about twice that in the calorimetric experiments; therefore, the solution of not more than $0.2 \mathrm{mg}$ of $(\mathrm{c}, \mathrm{I})$ (or $0.02 \%$ of $S$ ) would be expected in the experiments given in table 3. The acutal amount of $(c, I)$ which dissolved in water was so small and uncertain because of particle size that no correction was made for it.

Solutions prepared in the same manner as the calorimetric solutions of sodium hydroxide were analyzed by titration against weighed samples of potassium acid phthalate (NBS standard sample No. 84) using phenolphthalein in dicator. These analyses were only approximations since no special precautions were used to exclude carbon dioxide from the calorimetric solutions. An analysis of a solution prepared from stock soln No. 1 [used in reactions of $(\mathrm{c}, \mathrm{I})$ at $40^{\circ} \mathrm{C}$ ] indicated a normality of 1.94; a solution prepared from stock soln No. 3 [used in reactions of $\mathrm{H}_{3} \mathrm{BO}_{3}(\mathrm{c})$ at $25{ }^{\circ} \mathrm{C}$ ] was found to be $2.27 \mathrm{~N}$; and one prepared from stock soln No. 4 [used in reactions of $\mathrm{H}_{3} \mathrm{BO}_{3}$ at $40{ }^{\circ} \mathrm{C}$, and $(\mathrm{c}, \mathrm{II})$ at $40{ }^{\circ} \mathrm{C}$ and $25^{\circ} \mathrm{C}$ ] was $1.88 N$. Two stock solutions, $A$ and $B$, were used alternately in the preparation of calorimetric solutions for the experiments in Series III. Initial analysis of a solution prepared from stock soln A indicated a normality of 1.79 , and from stock soln B, 1.96; no change was observed in the final analyses of similar solutions.

\section{Units and Physical Constants}

The unit of energy for the calorimetric experiments reported in this paper is the absolute joule. For conversion to the thermochemical calorie, 1 thermochemical calorie $=4.1840 \mathrm{j}$.

Values for atomic weights were taken from the 1961 Table of Atomic Weights [16].

The masses of all samples given in the following tables have been corrected to the weights in vacuo using buoyancy factors calculated from densities given by Kracek, Morey, and Merwin [1].

\section{Experimental Results}

The heats of formation of the three metaboric acids were calculated from the heats of reaction of the metaboric acids and of orthoboric acid in water and in solutions of sodium hydroxide. The results of the experiments where these heats of reaction were determined are given in tables 2 through 6 . Tables 2 through 5 give details of experiments on which our "best values" are based, and in table 6 the average values of 4 to 6 experiments for all other reactions are given.

In all experiments $S$ is the weight (in vacuo) of sample in grams; $E_{a}$ is the energy equivalent of the initial system as determined from the electrical cali- 
Table 2. $\mathrm{HBO}_{2}(c, I I I)$ in water at $25^{\circ} \mathrm{C}$-Series $I I I$

\begin{tabular}{|c|c|c|c|c|c|c|c|c|c|c|}
\hline Expt. No. & $S$ & $\begin{array}{l}\mathrm{H}_{3} \mathrm{BO}_{3} \\
\text { total } \\
\text { titr. }\end{array}$ & $\underset{\text { ratio }}{\mathrm{H}_{3} \mathrm{BO}_{3}}$ & $\begin{array}{c}\mathrm{H}_{3} \mathrm{BO}_{3} \\
\text { eale. }\end{array}$ & $\begin{array}{l}\mathrm{HBO}_{2} \\
\text { (c,III) } \\
\text { calc. }\end{array}$ & $E_{a}$ & $\Delta R c$ & $Q$ & $q$ H3 В 03 & $\left.\Delta H\left(25^{\circ} \mathrm{C}\right)\right)^{1}$ \\
\hline $\begin{array}{l}1 \\
2 \\
3 \\
4 \\
5\end{array}$ & $\begin{array}{l}g \\
0.83071 \\
.64787 \\
.73979 \\
.66889 \\
.81347\end{array}$ & $\begin{array}{l}\text { Mole } \\
0.01824 \\
.01425 \\
.01621 \\
.01464 \\
.01788\end{array}$ & $\begin{array}{r}0.9623 \\
.9640 \\
.9604 \\
.9582 \\
.9633\end{array}$ & $\begin{array}{l}\text { Mole } \\
0.001747 \\
.001303 \\
.001637 \\
.001520 \\
.001666\end{array}$ & $\begin{array}{l}\text { Mole } \\
0.01649 \\
.01295 \\
.01457 \\
.01312 \\
.01621\end{array}$ & $\begin{array}{l}\text { j/obm } \\
21,313.7 \\
21,304.2 \\
21,315.3 \\
21,300.4 \\
21,319.8\end{array}$ & $\begin{array}{c}\text { Ohm } \\
-0.002740 \\
-.002212 \\
-.002643 \\
-.002361 \\
-.002845\end{array}$ & $\begin{array}{l}j \\
-58.40 \\
-47.12 \\
-56.34 \\
-50.29 \\
-60.65\end{array}$ & $\begin{array}{l}j \\
-38.0 \\
-28.3 \\
-35.6 \\
-33.1 \\
-36.2\end{array}$ & $\begin{array}{r}k j / m o l e \\
\mathrm{HBO}_{2}(\mathrm{c}, \mathrm{III}) \\
1.662 \\
1.994 \\
1.904 \\
1.844 \\
1.940\end{array}$ \\
\hline \multicolumn{10}{|c|}{$\begin{array}{l}\text { Mean } \\
\text { Standard deviation of the mean } \\
\text { Overall uncertainty, } 10 \%\end{array}$} & $\begin{aligned} & 1.869 \\
\pm & 0.057 \\
\pm & 0.19\end{aligned}$ \\
\hline
\end{tabular}

1 Another correction, $q_{d}=-7.0 \mathrm{j} /$ expt., was added to $Q$.

TABLe 3. $\mathrm{HBO}_{2}(c, I I)$ in water at $25^{\circ} \mathrm{C}$-Series $I I I$

\begin{tabular}{|c|c|c|c|c|c|c|c|c|}
\hline Expt. No. & $S$ & $\begin{array}{c}\text { Undis- } \\
\text { solved } \\
\text { Residue } \\
\mathrm{HBO}_{2}(\mathrm{c}, \mathrm{I}) \\
\text { titr. }\end{array}$ & $\begin{array}{l}\mathrm{HBO}_{2} \\
\text { titr. II) }\end{array}$ & $\begin{array}{c}\mathrm{H}_{3} \mathrm{BO}_{3} \\
\text { ratio }\end{array}$ & $E_{a}$ & $\Delta R c$ & Q & $\Delta H\left(25^{\circ} \mathrm{C}\right){ }^{1}$ \\
\hline $\begin{array}{l}5 \\
6 \\
6\end{array}$ & $\begin{array}{l}g \\
1.11827 \\
1.15561 \\
1.19328 \\
1.24525 \\
1.20517 \\
1.24061\end{array}$ & $\begin{array}{l}\text { Mole } \\
0.00016 \\
.00018 \\
.00008 \\
.00019 \\
.00026 \\
.00020\end{array}$ & $\begin{array}{l}\text { Mole } \\
0.02523 \\
.02615 \\
.02713 \\
.02816 \\
.02719 \\
.02802\end{array}$ & $\begin{array}{r}0.9951 \\
.9986 \\
.9994 \\
.9978 \\
.9983 \\
.9970\end{array}$ & $\begin{array}{l}\text { j/ohm } \\
21,314.1 \\
21,303.6 \\
21,318.3 \\
21,322.9 \\
21,286.4 \\
21,302.6\end{array}$ & $\begin{array}{r}\text { Ohm } \\
-0.008501 \\
-.008403 \\
-.009094 \\
-.009263 \\
-.009069 \\
-.009407\end{array}$ & $\begin{aligned} & j \\
&-181.19 \\
&-179.01 \\
&-193.87 \\
&-197.51 \\
&-193.05 \\
&-200.39\end{aligned}$ & 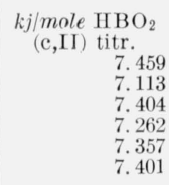 \\
\hline \multicolumn{8}{|c|}{$\begin{array}{l}\text { Mean } \\
\text { Standard deviation of the mean } \\
\text { Overall uncertainty, } 3 \%\end{array}$} & $\begin{aligned} & 7.333 \\
\pm & 0.051 \\
\pm & 0.220\end{aligned}$ \\
\hline
\end{tabular}

${ }^{1} \mathrm{~A}$ correction, $q_{d}=-7.0 \mathrm{j} / \mathrm{expt}$., was added to $Q$.

TABLE 4. $\mathrm{HBO}_{2}(c, I I)$ in $2 \mathrm{~N}$ sodium hydroxide solution at $25^{\circ} \mathrm{C}$-Series III

\begin{tabular}{|c|c|c|c|c|c|c|c|c|}
\hline Expt. No. & $S$ & $\begin{array}{c}\mathrm{HBO}_{2}(\mathrm{c}, \mathrm{I}) \\
\text { calc. }\end{array}$ & $\begin{array}{c}\mathrm{HBO}_{2}(\mathrm{c}, \mathrm{II}) \\
\text { calc. }\end{array}$ & $E_{a}$ & $\Delta R c$ & $Q$ & $q_{(\mathrm{c}, \mathrm{I})}$ & $\Delta H\left(25^{\circ} \mathrm{C}\right)^{1}$ \\
\hline $\begin{array}{l}1 \\
2 \\
3 \\
4\end{array}$ & $\begin{array}{c}g \\
1.08860 \\
1.23190 \\
1.32026 \\
1.39278\end{array}$ & $\begin{array}{c}\text { Mole } \\
0.000174 \\
.000197 \\
.000211 \\
.000222\end{array}$ & $\begin{array}{c}\text { Mole } \\
0.024670 \\
.027918 \\
.029920 \\
.031563\end{array}$ & $\begin{array}{c}j / \text { ohm } \\
21,175.9 \\
21,090.1 \\
21,133.0 \\
21,086.4\end{array}$ & $\begin{array}{c}\text { Ohm } \\
0.043611 \\
.049811 \\
.053130 \\
.056267\end{array}$ & $\begin{array}{r}j \\
923.50 \\
1050.52 \\
1122.80 \\
1186.47\end{array}$ & $\begin{array}{l}j \\
4.8 \\
5.4 \\
5.8 \\
6.1\end{array}$ & $\begin{array}{c}k j / \text { mole } \\
\mathrm{HBO} \mathrm{O}_{2}(\mathrm{c}, \mathrm{II}) \\
-36.956 \\
-37.185 \\
-37.099 \\
-37.175\end{array}$ \\
\hline \multicolumn{9}{|c|}{$\begin{array}{l}\text { Mean } \\
\text { Standard deviation of the mean } \\
\text { Overall uncertainty, } 2 \%\end{array}$} \\
\hline
\end{tabular}

1 Another correction, $q_{d}=-7.0 \mathrm{j} /$ expt. was added to $Q$.

TABLE 5. $\mathrm{HBO}_{2}(c, I)$ in $2 \mathrm{~N}$ sodium hydroxide solution at $25^{\circ} \mathrm{C}-$ Series III

\begin{tabular}{|c|c|c|c|c|c|}
\hline Expt. No. & $S$ & $E_{a}$ & $\Delta R c$ & $Q$ & $\Delta H\left(25^{\circ} \mathrm{C}\right)^{1}$ \\
\hline 1 & $\begin{array}{l}g \\
0.54449 \\
.26108\end{array}$ & $\begin{array}{l}j / \text { ohm } \\
21,067.7 \\
21,073.9\end{array}$ & $\begin{array}{l}\text { Ohm } \\
0.016479 \\
.008065\end{array}$ & $\begin{array}{l}j \\
347.17 \\
169.96\end{array}$ & $\begin{array}{l}\mathrm{kj} / \text { mole } \\
\mathrm{HBO}_{2}(\mathrm{e}, \mathrm{I}) \\
-27.375 \\
-27.350\end{array}$ \\
\hline \multicolumn{5}{|c|}{$\begin{array}{l}\text { Mean } \\
\text { Overall uncertainty, } 2 \%\end{array}$} & $\begin{array}{l}-27.362 \\
\pm 0.55\end{array}$ \\
\hline
\end{tabular}

1 A correction, $q_{d}=-7.0 \mathrm{j} / \mathrm{expt}$., was added to $Q$. bration which preceded each chemical reaction experiment; $\triangle R c$ is the corrected temperature rise of the system [13]; $Q$, the product of $E_{a}$ and $\triangle R c$, is the total energy absorbed by the system; and $\triangle H$, the enthalpy of reaction, is the heat absorbed $(-Q$, less any applicable corrections, $-q$ ) per mole of orthoboric acid or metaboric acid calculated from the weight of sample or determined from the number of moles of orthoboric acid found in the titrations of the final calorimetric solutions, $\mathrm{H}_{3} \mathrm{BO}_{3}$ titr. The overall uncertainty includes twice the experimental standard deviation of the mean and other uncertainties discussed in section 5.1. The $\mathrm{H}_{3} \mathrm{BO}_{3}$ ratio is the ratio of the number of moles of orthoboric acid found in 
TABLE 6. Average results of other solution experiments

\begin{tabular}{|c|c|c|c|c|c|c|c|c|c|c|c|c|c|}
\hline Group & Compound & Series & $S 1$ & $\begin{array}{c}\text { Undissolved } \\
\text { residue } \\
\mathrm{HBO}_{2}(\mathrm{c}, \mathrm{I}) \\
\text { titr. }\end{array}$ & $\begin{array}{c}\text { Calc. } \\
\mathrm{HBO}_{2}(\mathrm{c}, \mathrm{II}) \\
\text { or } \\
\mathrm{HBO}_{2}(\mathrm{c}, \mathrm{III})\end{array}$ & $\begin{array}{c}\mathrm{H}_{3} \mathrm{BO}_{3} \\
\text { titr. }\end{array}$ & $E_{a}$ & $\Delta R c$ & $Q$ & $\begin{array}{c}q(\mathrm{c}, \mathrm{I}) \\
\text { or } \\
q_{\mathrm{H} 3 \mathrm{BO} 3}\end{array}$ & $\begin{array}{c}\text { Dilution } \\
\mathrm{H}_{2} \mathrm{O} / \\
\mathrm{H}_{3} \mathrm{BO}_{3}\end{array}$ & $\begin{array}{c}\text { Exper- } \\
\text { imental } \\
\text { sdm }\end{array}$ & $\begin{array}{l}\Delta \mathrm{H}\left(40^{\circ} \mathrm{C}\right) \pm \\
\text { uncertainty }\end{array}$ \\
\hline & & & $g$ & $g$ & Mole & Mole & $j /$ ohm & Ohm & $j$ & $j$ & & $k j /$ mole \{ & $\left\{\begin{array}{l}\mathrm{kj} / \mathrm{mole} \\
\mathrm{kcal} / \mathrm{mole}\end{array}\right.$ \\
\hline \multicolumn{14}{|c|}{ Solutions in $2 N$ sodium hydroxide at $40^{\circ} \mathrm{C}$} \\
\hline 1 & $\mathrm{H}_{3} \mathrm{BO}_{3}(\mathrm{c})$ & I & $\begin{array}{l}1.64442 \\
(1.47-1.76)\end{array}$ & \multirow{3}{*}{0.0359} & & & \multirow{3}{*}{$\begin{array}{l}23,238.7 \\
23,222.7 \\
23,143.7\end{array}$} & \multirow{3}{*}{$\begin{array}{r}0.024556 \\
.049235 \\
.010105\end{array}$} & \multirow{3}{*}{$\begin{array}{r}570.65 \\
1,143.37 \\
233.85\end{array}$} & \multirow{3}{*}{32.2} & & \multirow{3}{*}{$\begin{array}{l} \pm 0.007 \\
\pm .077 \\
\pm .021\end{array}$} & \multirow{3}{*}{ 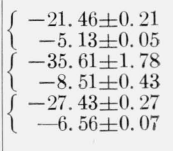 } \\
\hline 2 & $\mathrm{HBO}_{2}(\mathrm{c}, \mathrm{II})$ & I & $\begin{array}{l}1.45515 \\
(1.11-1.91)\end{array}$ & & & & & & & & & & \\
\hline 3 & $\mathrm{HBO}_{2}(\mathrm{c}, \mathrm{I})$ & I & $\begin{array}{l}0.37354 \\
(0.33-0.42)\end{array}$ & & & & & & & & & & \\
\hline \multicolumn{14}{|c|}{ Solutions in $2 N$ sodium hydroxide at $25^{\circ} \mathrm{C}$} \\
\hline 4 & $\mathrm{H}_{3} \mathrm{BO}_{3}(\mathrm{c})$ & I & $\begin{array}{l}0.59862 \\
(0.57-0.62)\end{array}$ & \multirow{4}{*}{0.0472} & \multirow[b]{4}{*}{0.013861} & \multirow{4}{*}{\multicolumn{2}{|c|}{\begin{tabular}{l|}
$22,859.7$ \\
$21,129.8$ \\
$22,884.8$ \\
$21,129.4$
\end{tabular}}} & \multirow{4}{*}{$\begin{array}{r}.009924 \\
.017354 \\
.047484 \\
.029520\end{array}$} & \multirow{4}{*}{$\begin{array}{r}226.86 \\
366.68 \\
1,086.60 \\
623.75\end{array}$} & \multirow{4}{*}{$\begin{array}{l}(2) \\
21.2 \\
233.8\end{array}$} & & \multirow{4}{*}{$\begin{array}{c} \pm 0.071 \\
\pm .044 \\
\pm .132 \\
\pm .62\end{array}$} & \multirow{4}{*}{$\begin{array}{c}\triangle H\left(25^{\circ} C\right) \pm \\
\text { uncertainty } \\
-23.43 \pm 0.23 \\
-5.60 \pm 0.06 \\
-22.90 \pm 0.34 \\
-5.47 \pm 0.08 \\
-36.87 \pm 1.84 \\
-8.81 \pm 0.44 \\
-42.07 \pm 2.10 \\
-10.05 \pm 0.50\end{array}$} \\
\hline 5 & $\mathrm{H}_{3} \mathrm{BO}_{3}(\mathrm{c})$ & III & & & & & & & & & & & \\
\hline 6 & $\mathrm{HBO}_{2}(\mathrm{c}, \mathrm{II})$ & I & $\begin{array}{l}\text { 1. } 34726 \\
(1.19-1.52)\end{array}$ & & & & & & & & & & \\
\hline 7 & $\mathrm{HBO}_{2}(\mathrm{c}, \mathrm{III})$ & III & $\begin{array}{l}0.69948 \\
(0.66-0.74)\end{array}$ & & & & & & & & & & \\
\hline \multicolumn{14}{|c|}{ Solutions in water at $25^{\circ} \mathrm{C}$} \\
\hline 8 & $\mathrm{H}_{3} \mathrm{BO}_{3}(\mathrm{c})$ & II & $\begin{array}{l}1.57140 \\
(1.38-1.70)\end{array}$ & & & 0.02530 & $21,000.1$ & -0.026502 & -556.55 & & 1000 & \pm 0.088 & 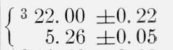 \\
\hline 9 & $\mathrm{H}_{3} \mathrm{BO}_{3}(\mathrm{c})$ & III & $\begin{array}{l}\text { 1. } 10529 \\
(1.06-1.14)\end{array}$ & & & 0.01784 & $21,276.1$ & -.017780 & -378.28 & $(2)$ & 1400 & \pm .024 & $\left\{\begin{array}{r}321.60 \pm 0.22 \\
5.16 \pm 0.05\end{array}\right.$ \\
\hline 10 & $\mathrm{HBO}_{2}(\mathrm{c}, \mathrm{II})$ & I & $\begin{array}{l}\text { 1. } 12472 \\
(1.10-1.17)\end{array}$ & 0.0647 & 0.024192 & & $23,122.8$ & -.007262 & -167.91 & & 1000 & \pm .057 & $\left\{\begin{array}{l}6.94 \pm 0.35 \\
1.659 \pm 0.083\end{array}\right.$ \\
\hline
\end{tabular}

1 The range of sample weights is given in parentheses below the average sample weight.

2 A correction, $\mathrm{q}_{\mathrm{d}}=-7.0 \mathrm{j} / \mathrm{expt}$., was also added in the experiments of Series III.

Based on moles $\mathrm{H}_{3} \mathrm{BO}_{3}$ titr.

titrations of the final calorimetric solutions to the number of moles of orthoboric acid calculated from the sample weight; $q_{d}$ is the correction for the energy required to break the platinum disks used in Series III.

The heats of solution of orthoboric acid in water at $25{ }^{\circ} \mathrm{C}$ and in sodium hydroxide solution at $25{ }^{\circ} \mathrm{C}$ and $40{ }^{\circ} \mathrm{C}$ are used in the calculations of the heats of formation of the three metaboric acids. The heat of solution in water at $25^{\circ} \mathrm{C}$ has been determined by several investigators $[2-5,10,19-25]$ and their values at a dilution of $1000 \mathrm{H}_{2} \mathrm{O}$ range from 5.17 $\mathrm{kcal} / \mathrm{mole}$ to $5.56 \mathrm{kcal} / \mathrm{mole}$; the more recent values are grouped between 5.24 and $5.28 \mathrm{kcal} / \mathrm{mole}$.

We have measured the heat of solution of orthoboric acid in water in two groups of experiments and the results are given in table 6 , groups 8 and 9 for Series II and Series III which are described in section 3.1. The samples in Series II were enclosed in glass bulbs which had been sealed after pumping for several hours at $10^{-5} \mathrm{~mm} H g$ pressure at room temperature; the samples in Series III were enclosed in the Monel capsule. The reaction periods for the experiments in group 8 were of 20 -min duration while those in group 9 were of 40-min duration, thus the latter should be nearer thermal equilibrium at the end of the reaction period.

According to Smisko and Mason [19] the heat of solution of orthoboric acid in water does not change significantly between the dilutions of $500 \mathrm{H}_{2} \mathrm{O}$ and $5000 \mathrm{H}_{2} \mathrm{O}$. Therefore no corrections for dilutions of
$\mathrm{H}_{3} \mathrm{BO}_{3}$ are made in this paper since all values fall within the range of 900 to $2700 \mathrm{H}_{2} \mathrm{O}$.

The data for the measurements of the heats of solution of orthoboric acid in sodium hydroxide solution at $40^{\circ} \mathrm{C}$ and at $25^{\circ} \mathrm{C}$ are given in table 6 , groups 1, 4, and 5. The largest uncertainty considered for these reactions was the possible variation in the concentration and/or composition of the calorimetric solutions of sodium hydroxide.

Our best value for the heat of transition from $(c, I I I)$ to $(c, I I)$ is derived from the heats of solution in water at $25^{\circ} \mathrm{C}$ (Series III) given in tables 2 and 3 , and group 9 of table 6. 'The equation representing' the mean heat of solution given in table 2 is

$$
\begin{gathered}
\mathrm{HBO}_{2}(\mathrm{c}, \mathrm{III})+1501 \mathrm{H}_{2} \mathrm{O}(\mathrm{liq}) \rightarrow \mathrm{H}_{3} \mathrm{BO}_{3}\left(1500 \mathrm{H}_{2} \mathrm{O}\right) \\
\begin{aligned}
\Delta H\left(25^{\circ} \mathrm{C}\right) & =1.869 \pm 0.187 \mathrm{kj} / \mathrm{mole} \\
& =0.447 \pm 0.045 \mathrm{kcal} / \mathrm{mole}
\end{aligned}
\end{gathered}
$$

and that for table 3 is

$$
\begin{gathered}
\mathrm{HBO}_{2}(\mathrm{c}, \mathrm{II})+901 \mathrm{H}_{2} \mathrm{O}(\text { liq }) \rightarrow \mathrm{H}_{3} \mathrm{BO}_{3}\left(900 \mathrm{H}_{2} \mathrm{O}\right) \\
\begin{aligned}
\Delta H\left(25^{\circ} \mathrm{C}\right) & =7.33 \pm 0.22 \mathrm{kj} / \mathrm{mole} \\
& =1.752 \pm 0.053 \mathrm{kcal} / \mathrm{mole}
\end{aligned}
\end{gathered}
$$

The experimental uncertainty, $2(\mathrm{sdm})$, is large for eq (1) because the amount of heat absorbed during 
the reaction was small. The uncertainty with respect to sample composition also made a relatively large contribution to the overall uncertainty for eq (2).

The heat of reaction in table 2 is based on the number of moles of (c,III) calculated from the stoichiometric relationship between the weight of sample and the amount of boric acid found in titrations of the final calorimetric solutions. The corrections for the energy absorbed during the solution of the orthoboric acid were calculated from the results of group 9 , table 6 . The composition of the samples in group 7 , table 6 was assumed to be the same as the average of those in table 2 .

In table 3 , the $\mathrm{H}_{3} \mathrm{BO}_{3}$ ratio is the ratio of the sum of the number of moles of (c,II) and of (c,I) titrated, to the number of moles of $\mathrm{HBO}_{2}$ calculated from the sample weight. From this it can be seen that only a few tenths of 1 percent of the sample weight was not accounted for in the titration analyses and this is within the limits of accuracy expected of the analytical methods employed. The extra care taken in the purification of this sample is evidenced by the fact that the amount of (c,I) impurity is much smaller and the composition of the samples is more uniform than those of the experiments in Series I given in group 10 of table 6 , on which the average composition, 6 percent of $(c, I)$, of the samples in groups 2 and 6 was based. The amount of $(c, I)$ dissolved during the latter experiments was determined from the difference between the amount assumed to be present initially and the amount found in the undissolved residue at the end of the experiment. A correction for the heat of reaction of the $(c, I)$ which dissolved, $q_{(\text {c. I ) }}$, was made using the results obtained in group 3 of table 6 and in table 5 . A large uncertainty with respect to composition of sample was considered in the results of groups 2, 6, and 10 ; groups 2 and 6 had an additional uncertainty in the concentration of sodium hydroxide solutions.

The results given in tables 4 and 5 were used with the results of group 5, table 6 , to calculate our best value for the heat of transition from (c,II) to (c,I). The mean heat of reaction for the experiments in table 4 is given by the equation,

$$
\begin{aligned}
& \mathrm{HBO}_{2}(\mathrm{c}, \mathrm{II})+\mathrm{NaOH}(\mathrm{aq}) \rightarrow\left[\mathrm{NaBO}_{2}+\mathrm{H}_{2} \mathrm{O}\right](\text { soln }) \\
& \Delta H\left(25^{\circ} \mathrm{C}\right)=-37.10 \pm 0.74 \mathrm{kj} / \mathrm{mole} \\
& =-8.87 \pm 0.18 \mathrm{kcal} / \mathrm{mole}
\end{aligned}
$$

and for those in table 5,

$$
\begin{aligned}
& \mathrm{HBO}_{2}(\mathrm{c}, \mathrm{I})+\mathrm{NaOH}(\mathrm{aq}) \rightarrow\left[\mathrm{NaBO}_{2}+\mathrm{H}_{2} \mathrm{O}\right](\text { soln }) \\
& \Delta H\left(25^{\circ} \mathrm{C}\right)=-27.36 \pm 0.55 \mathrm{kj} / \mathrm{mole} \\
& =-6.54 \pm 0.13 \mathrm{kcal} / \mathrm{mole} \text {. }
\end{aligned}
$$

The uncertainties in the compositions of the sodium hydroxide solutions and of the samples of (c,II) contributed largely to the overall uncertainties assigned to these equations. In table 4, the corrections for the heat evolved during the solution of
(c,I) was made according to eq (4) assuming $0.7 \mathrm{wt}$ percent of $(c, I)$ was present in the samples. This was the average composition found in the samples of table 3. A value comparable to eq (4) at $40^{\circ} \mathrm{C}$ is given in group 3 , table 6 .

The equations representing the reactions of orthoboric acid which were used with eqs (1), (2), and (4) in calculating our best values for the heats of formation of the metaboric acids given in table 8 are

$$
\begin{gathered}
\mathrm{H}_{3} \mathrm{BO}_{3}(\mathrm{c})+1400 \mathrm{H}_{2} \mathrm{O}(\mathrm{liq}) \rightarrow \mathrm{H}_{3} \mathrm{BO}_{3}\left(1400 \mathrm{H}_{2} \mathrm{O}\right) \\
\begin{aligned}
\Delta H\left(25^{\circ} \mathrm{C}\right) & =21.60 \pm 0.22 \mathrm{kj} / \text { mole } \\
& =5.16 \pm 0.05 \mathrm{kcal} / \mathrm{mole}
\end{aligned}
\end{gathered}
$$

and

$$
\begin{aligned}
& \mathrm{H}_{3} \mathrm{BO}_{3}(\mathrm{c})+\mathrm{NaOH}(\mathrm{aq}) \rightarrow\left[\mathrm{NaBO}_{2}+2 \mathrm{H}_{2} \mathrm{O}\right] \text { (soln) } \\
& \Delta H\left(25^{\circ} \mathrm{C}\right)=-22.90 \pm 0.34 \mathrm{kj} / \mathrm{mole} \\
& =-5.47 \pm 0.08 \mathrm{kcal} / \mathrm{mole} \text {. }
\end{aligned}
$$

The average values of the experimental data for these reactions are given in groups 9 and 5 of table 6 .

\subsection{Uncertainties}

The estimated error in the analyses of the products by titration was about 0.3 percent. An uncertainty in composition and weight of samples was considered because the samples could not be quantitatively analyzed as to crystal form. This uncertainty was highest in the samples of $(c, I I)$ or solution in sodium hydroxide where it was difficult to determine accurately the amount of $(c, I)$ impurity present initially or that which dissolved during the experiment. A greater uncertainty was present in the experiments where the products were not analyzed by titration and the composition of the sample was assumed to be the same as that of another series of experiments. An uncertainty was also considered for the solution of orthoboric acid samples in water in series I where the samples were enclosed in glass bulbs, because some decomposition may have occurred while the samples were under vacuum or during the sealing of the bulbs.

In section 3.3 the failure to reach thermal equilibrium in the calorimeter was discussed and possible errors of 2.0 percent were considered in extreme cases.

It was assumed that the uncertainty in the energy for breaking the platinum disks used in series III did not exceed $4 \mathrm{j}$ /expt. This assumption is based on the work described in section 3.2 where the energies for breaking the disks were determined when the capsule contained water, $\mathrm{NaCl}$, and $\mathrm{KCl}$.

For the experiments in Series I it had been assumed that the variations in the calorimetric sodium hydroxide solutions could be neglected. However, the experiments of Series III were arranged so as to expose any significant effects caused by the variations in the sodium hydroxide solutions on the heats of reaction and to nullify that effect on the heats of 
TABLE 7. Table showing the possible effects of time and different concentrations of sodium hydroxide solutions on the measured heats of reaction for experiments in Series III

\begin{tabular}{|c|c|c|c|c|}
\hline \multirow{3}{*}{ Sample No. } & & \multicolumn{3}{|c|}{$-\Delta H\left(25^{\circ} \mathrm{C}\right)$} \\
\hline & & \multicolumn{2}{|c|}{$\mathrm{NaOH}$ stock soln ${ }^{1}$} & \multirow{2}{*}{ Mean } \\
\hline & & A & B & \\
\hline \multirow[t]{2}{*}{$\mathrm{H}_{3} \mathrm{BO}_{3}(\mathrm{c})$} & 1 & kj/mole & $\begin{array}{l}\mathrm{kj} / \text { mole } \\
23.032\end{array}$ & $\mathrm{kj} / \mathrm{mole}$ \\
\hline & & 22.935 & 22.987 & 22.985 \\
\hline \multirow[t]{2}{*}{$\mathrm{HBO}_{3}(\mathrm{c}, \mathrm{III})$} & 1 & 43. 08 & ת & \\
\hline & & 42. 71 & & \\
\hline \multirow[t]{2}{*}{$\mathrm{HBO}_{3}(\mathrm{c}, \mathrm{II})$} & 1 & 36.956 & 37.18 .5 & 37.104 \\
\hline & $\begin{array}{l}3 \\
4\end{array}$ & 37. 099 & 37.175 & \\
\hline $\mathrm{HBO}_{2}(\mathrm{c}, \mathrm{I})$ & 1 & 27.350 & 27. 375 & 27.362 \\
\hline \multirow[t]{2}{*}{$\mathrm{HBO}_{2}(\mathrm{c}, \mathrm{III})$} & 4 & & 40.46 & \\
\hline & 6 & 40.51 & 41. 42 & 40.80 \\
\hline \multirow[t]{2}{*}{$\mathrm{H}_{3} \mathrm{BO}_{3}(\mathrm{c})$} & 4 & 22.832 & \multirow{2}{*}{22.836} & \multirow{2}{*}{ 22. 806} \\
\hline & 6 & 22.751 & & \\
\hline
\end{tabular}

1 Initial analysis of a calorimetric solution prepared from $\mathrm{NaOH}$ stock soln A indicated a normality of 1.79, and from stock soln B, 1.96; no change was indicated in similar analyses made 4 weeks later at the end of these experiments.

formation. These variations were caused by (1) slightly different compositions in the $10 N$ stock solutions, (2) changes in the composition of a given stock solution over a period of time, and (3) errors in the amounts weighed during the preparation of the calorimetric solutions. The method of preparing the calorimetric solutions and the analyses of the stock solutions are given in sections 3.1 and 3.4. All of the heats of reaction in sodium hydroxide at $25^{\circ} \mathrm{C}$ of series III are given in table 7 . 'Two stock solutions, A and B, were used alternately in the preparation of the calorimetric solutions for these experiments, and the experiments are arranged in the table in the chronological order in which they were run. The difference between the results obtained with the two stock solutions is small and within the limits of experimental error. However, a change in composition of the stock solutions with time is indicated by the fact that the results of the earlier experiments with $\mathrm{H}_{3} \mathrm{BO}_{3}$ and $(\mathrm{c}, \mathrm{III})$ have a higher mean heat of reaction than those of the comparable later experiments; we have no reason to suspect a change in the composition of the sample. Based on these results we have assigned an uncertainty of 3 percent for the reaction of (c,III) and 1 percent for all other reactions in sodium hydroxide solutions.

Although the overall uncertainties are large for the measured heats of reaction, most of them tend to cancel out in the calculatons of the heats of formation and transition.

\section{Discussion and Summary}

The heats of formation calculated from the various measured heats of reaction are summarized in table 8. $\Delta H_{r}$ was derived from the measured heats of reaction and is represented by the general equation

$$
\mathrm{HBO}_{2}(\mathrm{c}, X)+\mathrm{H}_{2} \mathrm{O}(\text { liq }) \rightarrow \mathrm{H}_{3} \mathrm{BO}_{3}(\mathrm{c}) \text {. }
$$

From this, the heats of formation of the metaboric acids were obtained using the following heats of formation at $25^{\circ} \mathrm{C}$ : $-262.16 \mathrm{kcal} / \mathrm{mole}$ for $\mathrm{H}_{3} \mathrm{BO}_{3}(\mathrm{c})$ $[11,28]$, and $-68.317 \mathrm{kcal} / \mathrm{mole}$ for $\mathrm{H}_{2} \mathrm{O}$ (liq) [17]. The uncertainties given in table 8 were calculated as the square root of the sum of the squares of the individual uncertainties; the largest uncertainty was $\pm 0.32 \mathrm{kcal} / \mathrm{mole}$ in the heat of formation of orthoboric acid. We have selected the following as the best values for the heats of formation of the metaboric acids at $25{ }^{\circ} \mathrm{C}:(\mathrm{c}, \mathrm{I}),-192.77 \pm 0.35 \mathrm{kcal} /$ mole; $(\mathrm{c}, \mathrm{II}),-190.43 \pm 0.34 \mathrm{kcal} / \mathrm{mole}$; and (c,III), $-189.13 \pm 0.34 \mathrm{kcal} / \mathrm{mole}$. These values agreed with the respective values of $-192.6,-190.6$, and -189.0 $\mathrm{kcal} /$ mole obtained by Prosen [18] from measurements of the equilibrium decomposition pressures of orthoboric acid into water vapor and the three metaboric acids.

The best values for the heats of transition were obtained from eq (1) and eq (2),

$$
\begin{aligned}
& \mathrm{HBO}_{2}(\mathrm{c}, \mathrm{III}) \rightarrow \mathrm{HBO}_{2}(\mathrm{c}, \mathrm{II}), \\
& \Delta H\left(25^{\circ} \mathrm{C}\right)=-1.30 \pm 0.05 \mathrm{kcal} / \mathrm{mole}, \\
& \text { and from eq (3) and eq (4) } \\
& \mathrm{HBO}_{2}(\mathrm{c}, \mathrm{II}) \rightarrow \mathrm{HBO}_{2}(\mathrm{c}, \mathrm{I}), \\
& \Delta H\left(25^{\circ} \mathrm{C}\right)=-2.33 \pm 0.23 \mathrm{kcal} / \mathrm{mole} .
\end{aligned}
$$

\begin{tabular}{|c|c|c|c|c|c|c|c|c|}
\hline Compound & $\begin{array}{l}\text { Calorimetric } \\
\text { solution }\end{array}$ & $\begin{array}{c}\Delta H\left(40^{\circ} \mathrm{C}\right) \\
\text { for } \mathrm{HBO}_{2}\end{array}$ & $\begin{array}{l}\Delta H\left(40{ }^{\circ} \mathrm{C}\right) \\
\text { for } \mathrm{H}_{3} \mathrm{BO}_{3}\end{array}$ & $H_{r}\left(40^{\circ} \mathrm{C}\right)$ & $\begin{array}{l}\Delta H\left(25^{\circ} \mathrm{C}\right) \\
\text { for } \mathrm{HBO}_{2}\end{array}$ & $\begin{array}{l}\Delta H\left(25^{\circ} \mathrm{C}\right) \\
\text { for } \mathrm{H}_{3} \mathrm{BO}_{3}\end{array}$ & $\Delta H_{r}\left(25^{\circ} \mathrm{C}\right)$ & $\Delta H f^{\circ}\left(25^{\circ} \mathrm{C}\right)$ \\
\hline $\mathrm{HBO}_{2}(\mathrm{c}, \mathrm{I})$ & $\begin{array}{l}\mathrm{NaOH} \\
\mathrm{NaOH}\end{array}$ & -6.56 & -5.13 & -1.43 & -6.54 & -5.47 & $\begin{array}{r}-1.07 \\
1-1.28\end{array}$ & $\begin{array}{l}-192.77 \pm 0.35 \\
-192.56 \pm 0.33\end{array}$ \\
\hline $\mathrm{HBO}_{2}(\mathrm{c}, \mathrm{II})$ & $\begin{array}{l}\mathrm{NaOH} \\
\mathrm{NaOH} \\
\mathrm{NaOH} \\
\mathrm{H}_{2} \mathrm{O} \\
\mathrm{H}_{2} \mathrm{O}\end{array}$ & -8.51 & -5.13 & -3.38 & $\begin{array}{r}-8.87 \\
-8.81 \\
1.66 \\
1.75\end{array}$ & $\begin{array}{r}-5.47 \\
-5.60 \\
-5.26 \\
5.16\end{array}$ & $\begin{array}{r}-3.40 \\
-3.21 \\
-3.23 \\
-3.60 \\
-3.41\end{array}$ & $\begin{array}{r}-190.44 \pm 0.38 \\
2-190.63 \pm 0.55 \\
2-190.61 \pm 0.55 \\
2-190.24 \pm 0.35 \\
-190.43 \pm 0.34\end{array}$ \\
\hline $\mathrm{HBO}_{2}(\mathrm{c}, \mathrm{III})$ & $\begin{array}{l}\mathrm{H}_{2} \mathrm{O} \\
\mathrm{NaOH}\end{array}$ & & & & $\begin{array}{r}0.45 \\
-10.05\end{array}$ & $\begin{array}{r}5.16 \\
-5.47\end{array}$ & $\begin{array}{l}-4.71 \\
-4.58\end{array}$ & $\begin{array}{r}-189.13 \pm 0.34 \\
2-189.26 \pm 0.61\end{array}$ \\
\hline
\end{tabular}

TABLE 8. Heats of formation of the metaboric acids as calculated from various reactions (kcal/mole)

1 Estimated thermal coefficient, $\Delta C p \sim-10 \mathrm{cal} / \mathrm{deg}$ mole.

2 These values are subject to large uncertainties in the composition of the samples. 
Combination of these two values gives the following heat of transition:

$$
\begin{aligned}
\mathrm{HBO}_{2}(\mathrm{c}, \mathrm{III}) \rightarrow & \mathrm{HBO}_{2}(\mathrm{c}, \mathrm{I}), \\
& \Delta H\left(25^{\circ} \mathrm{C}\right)=-3.63 \pm 0.24 \mathrm{kcal} / \mathrm{mole} .
\end{aligned}
$$

Roth, Börger, and Bertram [3] measured the heat of solution of a mixture of metaboric acid and orthoboric acid in $0.1 \mathrm{~N}$ sodium hydroxide solution at $19^{\circ} \mathrm{C}$. The crystalline form of the metaboric acid used was not identified; however, they state that the bydration and solution of the metaboric acid may not have been complete in the experiments. This would suggest that their sample contained the monoclinic form which reacts more slowly than the orthorbombic form and usually contains $(c, I)$. They calculate a heat of solution for the metaboric acid, $\Delta H\left(19^{\circ} \mathrm{C}\right)=-8.0$ $\mathrm{kcal} / \mathrm{mole}$, which is comparable to our value for the monoclinic form given in eq (3).

In the work of von Stackelberg, Quatram, and Dressel [5], the heat of solution in water was measured at a dilution of $500 \mathrm{H}_{2} \mathrm{O} / \mathrm{H}_{3} \mathrm{BO}_{3}$ at $20{ }^{\circ} \mathrm{C}$ for a mixture of orthoboric acid and metaboric acid. Although their metaboric acid was crystallographically identified as the monoclinic form, they obtained a heat of solution (after correcting for the orthoboric acid) of $0.56 \mathrm{kcal} / \mathrm{mole}$ which is near the value we obtained in eq (1) for the orthorhombic form.

The more recent work of Sokolova and coworkers [6] yielded the following values for the heats of solution at $20{ }^{\circ} \mathrm{C}$ at a final dilution of $500 \mathrm{H}_{2} \mathrm{O}$ / $\mathrm{H}_{3} \mathrm{BO}_{3}: \Delta H=0.47 \mathrm{kcal} / \mathrm{mole}$ for the orthorhombic, $\mathrm{HBO}_{2}(\mathrm{c}, \mathrm{III})$; and $\Delta H=1.76 \mathrm{kcal} / \mathrm{mole}$ for the monoclinic, $\mathrm{HBO}_{2}(\mathrm{c}, \mathrm{II})$. These values are in good agreement with our eq (1) and eq (2). Their heat of transition from the orthorhombic to the monoclinic metaboric acid is $-1.29 \mathrm{kcal} / \mathrm{mole}$ which agrees with our value of $-1.30 \mathrm{kcal} / \mathrm{mole}$.

\section{References}

[1] F. C. Kracek, G. W. Morey, and H. E. Merwin, Am. J. [5] Sci. 35A, 143 (1938).

[2] W. A. Roth and E. Börger, Ber. 70B, 48 (1937).

[3] W. A. Roth, E. Börger, and A. Bertram, Ber. zoB, 971 (1937).

[4] W. A. Roth, Z. Naturforsch. 1, 574 (1946).

[5] M. von Stackelberg, F. Quatram, and J. Dressel, Z. Elektrochem. 43, 14 (1937).

[6] N. D. Sokolova, S. M. Skuratov, A. M. Shemonaeva, and V. M. Yuldasheva, Zhur. Neorg. Khim. 6, 774 (1961).

[7] M. V. Kilday and E. J. Prosen, J. Am. Chem. Soc. 82, $5508(1960)$

[8] J. H. Hibben, Am. J. Sci. [5] 35A, 113 (1938).

[9] H. Tazaki, J. Science Hiroshima Univ. Ser. A 10, 37 (1940); ibid., 109

[10] M. V. Kilday, W. H. Johnson, and E. J. Prosen, J. Res. NBS 65A, (Phys. and chem.) 435 (1961).

[11] E. J. Prosen, W. H. Johnson, and F. Y. Pergiel, J. Res. NBS 62, 43 (1959) RP2927.

[12] W. H. Johnson, A. A. Gilliland, and E. J. Prosen, J. Res. NBS 63A, 161 (1959).

[13] E. J. Prosen, Experimental Thermochemistry, F. D. Rossini, ed., ch. 6, Vol. I (Interscience Publishers, Inc., New York, N.Y., 1936).

[14] S. R. Gunn and L. G. Green, J. Phys. Chem 64, 1066 (1960).

[15] V. S. Barfield, NBS, private communication (1961).

[16] A. E. Cameron and E. Wichers, J. Am. Chem. Soc. 84, 4175 (1962).

[17] F. D. Rossini, D. D. Wagman, W. H. Evans, S. Levine, and I. Jaffe, Selected values of chemical thermodynamic properties, NBS Circ. 500 (U.S. Government Printing Office, Washington, D.C., 20402, 1952).

[18] E. J. Prosen, NBS, unpublished data (1960).

[19] H. L. Johnston, H. N. Hersh, and E. C. Kerr, J. Am. Chem. Soc. 73, 1112 (1951).

[20] N. S. Osborne, H. F. Stimson, and D. C. Ginnings, J. Res. NBS 23, 197 (1939) RP1228.

[21] J. Smisko and L. S. Mason, J. Am. Chem. Soc. 72, 3679 (1950).

[22] E. R. Van Artsdalen and K. P. Anderson, J. Am. Chem. Soc. 73, 579 (1951).

[23] K. Linderstrøm-Lang, Compt. rend. trav. lab. Carlsberg, Ser. chim. 15, No. 4, 65pp (1924).

[24] M. Berthelot, Ann. chim. phys. [5] 17, 132 (1879).

[25] J. Thomsen, Thermochemische Untersuchungen, Vols. I-IV (Verlag J. A. Barth, Leipzig. 1882-1886).

[26] C. Katz, MS Thesis, Cornell University (1949); quoted in $[22]$.

[27] W. C. Blasdale and C. M. Slansky, J. Am. Chem. Soc. 61, 917 (1939).

[28] W. H. Evans, E. J. Prosen, and D. D. Wagman, Thermochemistry and Thermodynamic Functions of Some Boron Compounds in Thermodynamic and transport properties of gases, liquids, and solids, p. 231, Y. S. Touloukian, ed. (McGraw-Hill Book Co., Inc., New York, N.Y., 1959). 


\section{Publications of the National Bureau of Standards*}

\section{Selected Äbstracts}

\author{
Solutions of the equation $\Psi_{x x}+\frac{1}{x} \Psi_{x}+K x^{n} e \Psi=0$, E. A. \\ Kearsley, J. Res. NBS 6rB (Math. and Math. Phys.), No. \\ 4, (Oct.-Dec. 1963).
}

The general solution of the equation $\Psi_{x x}+\frac{1}{x} \Psi_{x}+K x^{n} e \Psi=0$ is displayed in terms of simple tabulated functions. The existence and uniqueness of solutions of a simple boundary value problem are determined as a function of the parameter $K$.

On the graphs of finite idempotent Boolean relation matrices, D. Rosenblatt, J. Res. NBS 6rB (Math. and Math. Phys.), No. 4, (Oct.-Dec. 1963).

This paper presents a graph-theoretic characterization of idempotent Boolean relation matrices of finite order. A relation-theoretic point of view is adopted in the paper. Idempotent matrices appear in the sequence of powers of any Boolean relation matrix, and are of purely theoretical as well as applied interest in connection with issues of convergence. The results provide a detailed description of the connectivity and cyclic structure of the directed graphs of idempotent matrices. The study is basically motivated by certain connectivity and flow problems which arise in the analysis of large-scale information systems. The formal results are exemplified in an investigation of the asymptotic forms of a recursive model of an information system which affords a conjoint representation of processes of communication and derivation of information. A second principal application is given in a process formulation for the generation of consistent rank orderings. The relation between system design and idempotent forms is exhibited in the two applications.

Long waves associated with disturbances produced in plasmas, H. Bremmer, J. Res. NBS 68D (Radio Sci.), No. 1, (Jan. 1964).

The disturbances produced in a homogeneous plasma by passing charges is analyzed.

Reflection of electromagnetic waves from a lossy magnetoplasma, J. R. Wait and L. C. Walters, J. Res. NBS 68D (Radio Sci.), No. 1, (Jan. 1964).

A method is outlined for calculating the reflection coefficient from a horizontally stratified ionized medium. The profiles of electron density and the collision frequencies are both taken to be exponential functions. The d-c magnetic field is taken to be horizontal and transverse to the direction of propagation. The specific results described are applicable to the oblique reflection of VLF radio waves in the $D$ layer of the ionosphere for propagation along the magnetic equator. It is confirmed that the reflection coefficient is nonreciprocal in both am plitude and phase. For a wide range of the parameters, the magnitude of the reflection coefficient is greater for west-to-east propagation than for east-to-west propagation.

Electron optical studies of low-pressure gases, L. Marton, D. C. Schubert, and S. R. Mielczarek, NBS Mono. 66 (Aug. $16,1963), 35$ cents.

This document is the final report of research carried on in the Electron Physics Section of the National Bureau of Standards during the period from February 1, 1955 to March of 1962 in developing an electron optical method for the visualization of low-pressure gas flow. The goal of this work was to develop and demonstrate the suitability of electron optical techniques for recording the spatial distribution of gas molecules at fixed times with sufficient accuracy that the velocity distribution could be derived. The work concentrated on the properties of chopped molecular beams of cadmium at extremely low pressures where the densities of the particles in the molecular beam pulse correspond to a pressure of less than $10^{-7}$ Torr. The project was successful. During the course of this program, equipment was built, methods of operation were developed, the theory of the electron optical schlieren was developed in some detail, and ways of efficiently converting the data obtained into velocity distributions of the gas molecule were investigated.

Experimental statistics, M. G. Natrella, NBS Handb. 91 (Aug. 1, 1963), \$4.25.

This Handbook is a collection of statistical procedures which are useful in research and development programs. It is intended for the user with a scientific or engineering background who has an occasional need for statistical techniques, but does not have the time or inclination to become an expert on statistical theory or methodology. It is organized in five sections. Section 1 provides an elementary introduction to basic statistical concepts and furnishes full details on standard statistical techniques for the analysis and interpretation of measurement data. Section 2 provides detailed procedures for the analysis and interpretation of enumerative and classificatory data. Section 3 has to do with the planning and analysis of comparative experiments. Section 4 is devoted to consideration and exemplification of a number of important but as yet non-standard statistical techniques, and to discussion of other special topics. Section 5 contains all the mathematical tables needed for application of the procedures given in Sections 1 through 4.

Proceedings of the 1962 Standards Laboratory Conference, NBS Misc. Publ. 248 (Aug. 16, 1963), \$1.75.

This publication comprises technical papers together with discussions thereof, presented at the 1962 Standards Laboratory Conference, August 8-10, 1962.

Choking two-phase flow literature summary and idealized design solutions for hydrogen, nitrogen, oxygen, and refrigerants 12 and 11, R. V. Smith, NBS Tech. Note 179 (Aug. 3, 1963), 75 cents.

The literature summary presents a brief description and discussion of papers on choking, two-phase flow. These papers are arranged with respect to analysis methods and experimental systems. The idealized solutions utilize models intended to provide upper and lower limits for the actual flow cases. Charts are presented to provide for rapid determination of choking flow for the choking point condition and for Fanno and isentropic flow for the fluids $\mathrm{H}_{2}, \mathrm{~N}_{2}, \mathrm{O}_{2}$, $\mathrm{CCl}_{2} \mathrm{~F}_{2}$, and $\mathrm{CCl}_{3} \mathrm{~F}$. A discussion of choking flow and relaxation phenomena is included.

Report of the investigation of slow-flow meters for fuel oil distribution systems, D. R. Mackay, NBS Tech. Note 196 (Sept. 5, 1963), 20 cents.

A recent development in the retail distribution of fuel oil to individual residences and to mobile homes involves the use of small, slow-flow meters. A technical investigation was conducted by the Office of Weights and Measures to develop testing equipment and test procedures that could be used to evaluate the accuracy characteristics of these meters. This report describes the testing systems and test procedures that were developed, as well as the data that were obtained during the course of the investigation.

Research on crystal growth and characterization at the National Bureau of Standards during the period January to June 1963, Ed. by H. S. Peiser, NBS Tech. Note 197 (Sept. 23, 1963), 30 cents.

The National Bureau of Standards with partial support from 
the Advanced Research Projects Agency is continuing diverse research projects on the growth and characterization of crystals. This note summarizes the individual NBS activities in this and closely related fields during January to July 1963. Lists of NBS publications appertaining to that period and of participating NBS scientists are appended.

Monte Carlo calculations of the penetration and diffusion of fast charged particles, M. J. Berger, Book, Methods in Computational Physics, Ed. B. Alder, S. Fernbach, and M. Rotenberg, I, 135-215 (Academic Press, Inc., New York, N.Y., 1963). This is an expository article describing a Monte Carlo method for treating the multiple Coulomb scattering of fast charged particles. The method involves the setting up of a schematized random walk each step of which takes into account the effect of many successive collisions, and this random walk is simulated by random sampling. The transition probabilities for the random walk are obtained from the appropriate multiple scattering theories, including those of Moliere, Goudsmit and Saunderson, Landau, etc. After a detailed description of the required computational procedures, a review is given of the results that have been obtained by this method. The problems discussed include the backscattering and transmission of electrons and positrons by foils, the spatial distribution of energy dissipation by electrons, the slowing-down spectrum and pathlength distribution of electrons, and the penetration of protons. Numerous comparisons are made with experiments and other calculations.

Infrared dispersion of some oxide glasses, I. H. Malitson, G. W. Cleek, O. N. Stavroudis, and L. E. Sutton, Appl. Opt. 2, 741 (July 1963).

The refractive indices of four types of oxide glasses were measured for the wavelength range from $0.4 \mu$ to $5.3 \mu$. The experimental data were fitted to a Sellmeier dispersion equation of the form $n_{2}=1+\Sigma A j \lambda^{2} /\left(\lambda^{2}-\lambda j^{2}\right)$. Dispersive curves were plotted which indicate the expected dispersive power contribution to chromatic aberration, and spectral limit of resolution of the glasses as a function of wavelength. An attempt was made to correlate the parameters of the dispersion equation with the chemical composition of the glasses.

The structure of hexagonal silver iodide, G. Burley, $J$. Chem. Phys. 38, No. 12, 2807-2812 (June 1963).

A detailed three dimensional refinement of the structure of hexagonal silver iodide from room temperature photographic data showed very little deviation from the ideal wurtzitetype structure. Using anisotropic temperature factors a final $R$ value of $7.4 \%$ was obtained. The space group is $\mathrm{P}_{3}$ me. $\quad a=4.592, c=7.510, c / a=1.635, \mu=0.374_{4}$. A general linear relation of the position parameter $\mu$ to the $c / a$ axial ratio was found to apply to compounds having this structure type.

Radiolysis of propane- $d_{8}$ in the presence of organic compounds other than hydrocarbons, I. B. Sandoval and P. J. Ausloos, J. Chem. Phys. 38, No. 10, 2454-2460 (May 15, 1963).

The gas phase radiolysis of propane- $d_{8}$ has been investigated in the presence of dimethylmercury, azomethane, acetone, methyliodide, methanol, nitromethane and methylamine. The cross section of the hydride transfer reaction

$$
\mathrm{C}_{2} \mathrm{D}_{5}{ }^{+}+\mathrm{RH} \rightarrow \mathrm{C}_{2} \mathrm{D}_{5} \mathrm{H}+\mathrm{R}^{+}
$$

is, in all cases, at least ten times smaller than that of the reaction

$$
\mathrm{C}_{2} \mathrm{D}_{5}++\mathrm{C}_{3} \mathrm{D}_{8} \rightarrow \mathrm{C}_{2} \mathrm{D}_{6}+\mathrm{C}_{3} \mathrm{D}_{7}+
$$

Evidence for the occurrence of the proton transfer reaction

$$
\mathrm{C}_{2} \mathrm{D}_{5}++\mathrm{RH} \rightarrow \mathrm{C}_{2} \mathrm{D}_{4}+\mathrm{RHD}^{+}
$$

has been obtained. For the mixtures containing methanol, the cross section of this proton transfer reaction is about fifty times that of the hydride transfer process. Approximate values of $\mathrm{G}\left(\mathrm{CH}_{3}{ }^{+}\right)$have been determined for most of the additives.
Stark energy levels of symmetric-top molecules, J. H. Shirley, J. Chem. Phys. 38, 2896-2913 (June 15, 1963).

Calculations have been performed to determine the Stark energy levels of rigid symmetric top molecules. The continued fraction expression for the eigenvalues of the energy matrix is presented and techniques of evaluation described. Tables of reduced energy levels as a function of electric field are given for all rotational states through $J=4$. Graphs of these values and the effective dipole moments are included.

The microwave spectrum of normal propyl chloride, T. N. Sarachman, J. Chem. Phys. 39, No. 2, 469-473 (July 15, 1963). The microwave spectrum of gaseous normal propyl chloride reveals the presence of two rotational isomers, the trans and gauche conformations. The ground vibrational state rotational constants found for the more abundant $\mathrm{Cl}^{35}$ species are, for the gauche form, $A=11829.22, B=3322.58, C=2853.06$ $\mathrm{Mc} / \mathrm{sec}$; for the trans form, $B=2379.7, C=2271.7 \mathrm{Mc} / \mathrm{sec}$. Analysis of quadrupole hyperfine splittings in the spectrum of the gauche form gives the quadrupole coupling constants $\chi_{a a}=-19.41 \mathrm{Mc} / \mathrm{sec}, \eta=2.10_{5}$, in the principal axis system of the $\mathrm{Cl}^{35}$ species. Satellite spectra rising from excited vibrational states were also observed: in the gauche form, the first and second excited states of the skeletal torsion were assigned, and another satellite is believed to be from the excited methyl torsion; in the trans form, only the first excited state of the skeletal torsion was assigned. From relative intensity measurements, it is concluded that the energy difference between the trans and gauche isomers is $0 \pm .5$ $\mathrm{kcal} / \mathrm{mole}$.

Vacuum ultraviolet photochemistry. VI. Photolysis of cyclopropane with the Xenon resonance lines, C. L. Currie, H. Okabe, and J. R. McNesby, J. Phys. Chem. 6\%, No. \%, 1494-1497 (July 1963)

The photolysis of cyclopropane has been carried out at 1470 $\AA$ at room temperature.

The relative vields of products as well as isotopic analyses of hydrogen, metbane, and ethylene resulting from the photolysis of equimolar mixtures of cyclopropane and cyclopropane- $\mathrm{d}_{6}$ indicate the following primary processes in order of decreasing importance.

$$
\begin{gathered}
\mathrm{c}-\mathrm{C}_{3} \mathrm{H}_{6} \rightarrow \mathrm{CH}_{2}+\mathrm{C}_{2} \mathrm{H}_{4} \\
\mathrm{c}-\mathrm{C}_{3} \mathrm{H}_{6} \rightarrow \mathrm{H}_{2}+\mathrm{C}_{3} \mathrm{H}_{4} \\
\mathrm{c}-\mathrm{C}_{3} \mathrm{H}_{6} \rightarrow \mathrm{H}+\mathrm{C}_{3} \mathrm{H}_{5}
\end{gathered}
$$

Atomic hydrogen probably forms molecular hydrogen by wall recombination. It is suggested that methane and ethane are formed from the methyl radical produced in the reaction:

$$
\mathrm{CH}_{2}+\mathrm{c}-\mathrm{C}_{3} \mathrm{H}_{\mathrm{e}} \rightarrow \mathrm{c}-\mathrm{C}_{3} \mathrm{H}_{5} \mathrm{CH}_{3} * \rightarrow \mathrm{CH}_{3}+\mathrm{C}_{3} \mathrm{H}_{5}
$$

The mechanism of formation of other products is discussed briefly.

Atomic frequency standards at the National Bureau of Standards, J. M. Richardson, R. E. Beehler, R. C. Mockler, and R. L. Fey, Comite Consultatif, Definition de la Seconde aupres du Comite Intern. des Poids et Measures, pp. 57-67 (Sept. 1962).

Many laboratories in various countries have now shown that certain atomic resonance frequencies have such desirable properties that they may be considered suitable for a definition of the unit of time. Details in the performance of actual atomic resonance devices are given. Also, estimates are made of how closely a given device approaches the idealized resonance frequency. Recently, two cesium beam frequency standards of independent design and construction have been completed, evaluated, and compared at Boulder. The main characteristics and performance details of these standards are analyzed and listed.

An analysis is given of comparisons of the U.S. Frequency Standard, by standard frequency broadcasts, with other frequency standards in the world. 
Whistlers, R. M. Gallet, Grenoble, Univ. Ecole Phys, Theorique, Les Houches, Geophysique Exterieur, pp. 551-590 (Gordon and Breach, New York, N.Y., 1963).

The whistlers and the very low frequency emissions (VLF Emissions) are two different classes of natural radio phenomena observed at very low frequency (few kilocycles per second). Both classes are characterized by very distinctive variations of frequeney with time, which give them quasimusical qualities in listening. They can be heard after the voltage, which the electromagnetic signals induce in an antenna, is amplified by a wide band audio-amplifier without frequency conversion. Their principal physical interest is that their characteristics are directly due to the structure of the Earth's exosphere. They can be considered as natural and highly sensitive electromagnetic probes for studying the physics of the exosphere. In both classes a radio-propagation phenomenon is experienced, which has the unique property of guiding the energy of radio waves along curved paths defined by the magnetic lines of force of the Earth's magnetic field. These paths reach far out into space, as far as 3 or 4 earth's radii in the plane of the magnetic equator, and bring the energy back to earth at the point in the opposite hemisphere which is the magnetic conjugate of the position of the radio emission in the case of the whistlers. The length of such one way path can easily be as long as 30,000 to 50,000 $\mathrm{km}$. Furthermore, the energy can be almost perfectly reflected at the end of the path, and propagating again along the same path can be received in the area near the original point of emission. Along such long paths the speed of propagation of the energy is very slow (as low as c/10 to c/100), and its local value depends strongly on frequency.

Theory of the deep penetration of electrons and charged particles, L. V. Spencer and J. Coyne, Phys. Rev. 128, No. 5 , 2230-2237 (Dec. 1, 1963).

Charged particle penetration is amenable to elementary analysis if the continuous-slowing-down, small-angle, and diffusion-in-angle approximations are made. Such calculations are carried out in this paper, partly for their own interest and partly to demonstrate procedures of use in more realistic calculations. The present calculations can be considered an extension of Yang's work to problems including energy loss. One section of the paper goes beyond the approximation of diffusion-in-angle to derive results for a scattering function with a large-angle tail.

Correlation effects in two- and three-electron systems, J. W. Cooper and J. B. Martin, Phys. Rev. 131, No. S, 11831186 (Aug. 1, 1963).

Correlation effects in the lithium isoelectronic series $(1 \mathrm{~s})^{2} 2 \mathrm{~s}{ }^{2} \mathrm{~S}$ have been studied by computing the expectation values of a number of one- and two-electron operators. Calculations were performed using both Hartree-Fock and configuration interaction wave functions.

For comparison purposes the same expectation values were computed from configuration interaction wave functions of comparable accuracy for the two electron systems $(1 \mathrm{~s})^{21} \mathrm{~S}$. The main conclusions are (a) correlation has little effect on the one-electron expectation values, (b) the expectation values of ${ }_{i}>_{i}\left(r_{i} \cdot r_{j}\right)$ and $>_{i}\left(p_{i} \cdot p_{i}\right)$ are proportionately larger for threethan for two-electron systems, and (c) the configuration interaction approach probably gives poor estimates of the expectation values of $i>{ }_{j} \delta^{3}\left(r_{i j}\right)$ even though this value appears to converge as the number of terms in the wave function is increased.

Mechanical and electrical relaxation in theorium oxide containing calcium oxide, J. B. Wachtman, Jr., Phys. Rev. 131, 517 (July-Sept. 1963).

The dynamic behavior of oxygen vacancies associated with the solid solution of $\mathrm{CaO}$ in $\mathrm{ThO}_{2}$ is treated using an 8-position nearest neighbor model. This treatment predicts an internal friction peak characterized by a single relaxation time and a dielectric loss peak with a single relaxation time equal to twice the mechanical relaxation time. Both peaks have been observed and are in accord with these predictions within experimental error. The activation energy for the motion of an oxygen vacancy neighboring a substitutional $\mathrm{Ca}$ ion in $98.5 \mathrm{ThO}_{2}+1.5 \mathrm{CaO}$ is $0.93 \pm .02$ e.v.
A study of embrittlement of high strength steels by hydrogen isotopes. I. Testing of steel rings as specimens, a comparison of hydrogen and deuterium embrittlement, and permeation studies, G. B. Wood, J. Electrochem. Soc. 110, No. 8, 867-87y (Aug. 1963).

The embrittling nature of deuterium in steel is demonstrated. A comparison of the retention of embrittlement with retained gas content in uncoated steel is discussed. The separation factor for the electrodeposition of hydrogen and denterium on SAE 4130 steel was found to be 5.9. Permeation of the mixture of these isotopes through steel resulted in further enrichment with respect to hydrogen. The diffusion coefficients and permeation rates for hydrogen and deuterium in steel were compared.

A study of embrittlement of high strength steels by hydrogen isotopes. II. A comparison of gas contents and hydrogen or deuterium embrittlement resulting from electroplating processes, G. B. Wood, J. Electrochem. Soc. 110, No. 8, 877-885 (Aug. 1963).

Plating processes introduce more deuterium into steel from heavy water solutions than hydrogen from ordinary water solutions, yet hydrogen embrittles steel more than deuterium. There is no simple relation between the total gas content and embrittlement. Embrittlement appears to be dependent on factors other than the total gas content. The present work does not preferentially support any one of the mechanisms which have been proposed for hydrogen embrittlement. The difference in the chemical affinity of steel for hydrogen and deuterium is demonstrated.

Optical observation of pressure induced transitions in polymers, A. Van Valkenburg and J. Powers, J. Appl. Phys. 34, No. 8, 2433-2434 (Aug. 1963).

Pressure induced transitions in polytetrafluoroethylene, nylon 6, natural rubber, and polyethylene were observed optically between diamond anvils. In all polymers examined, the decrease in thickness and in birefringence is irreversible, at least on the time scale of a few months.

Visual observations of high pressure transitions, A. Van Valkenburg, Rev. Sci. Instr. Letter 33, No. 12, 1462 (Dec. 1962).

Phase changes at routine pressures of 70 kilobars have been visibly observed in transparent solids and liquids using a diamond squeezer cell and polarizing microscope.

Some intra-atomic correlation correction studies, M. Krauss and B. J. Ransil, J. Chem. Phys. 33, 840 (1960).

The applicability of the "intra-atomic correlation correction" (ICC) formulation of Hurley is discussed. It is shown that accurate bond energies can not be obtained with the usual restricted basis set without employing another empirical procedure although it may be possible to obtain accurate excitation energies.

Band spectrum analysis of mercury hydride, T. L. Porter, J. Opt. Soc. Am. 52, 1201 (1962).

The emission spectrum of mercury hydride has been photographed in the second and third orders of a 21-foot concave grating in the region 2930-4550 A. The light source was an electrodeless discharge tube containing a drop of mercury in an atmosphere of hydrogen and argon. Twenty-six bands of the $A-X$ system and four bands of the $B-X$ system have been analyzed, most of them to their predissociation limits. A table of these bands and a vibrational energy-level diagram are given. The behavior of the lambda-type doubling in the ${ }^{2} \Pi$ state for which the electronic coupling is Hund's case $a$ is compared with the theoretical prediction.

Remarks on coincidence experiments with visible light, Z. Bay and P. S. Farago, Proc. Royal Soc. Edinburgh, Sec. A. Math. and Phys. Sci. LXVI, pt. 11, No. 10, 111-115 (Royal Society of Edinburgh, Edinburgh, Scotland, 1963).

After the detection of correlations in two coherent light beams by Hanbury, Brown, and Twiss, objections were raised by Brannan and Ferguson on the basis of the experiments of Adam, Janossy, and Varga and their own experiments in which no correlations were detected. It is pointed out here 
that the opposing groups were looking for two entirely different effects, one being quadratic, the other one linear in the number or photons involved. The quadratic effect is in agreement with photon theory while the linear effect is not and therefore the experimental proof of the existance or nonexistence of the linear effect is of fundamental importance. It was shown by Purcell and by Hanbury, Brown, and Twiss that the choice of parameters in the experiments of Janossy and Brannen and Ferguson was inadequate to show the quadratic effect. It is shown in this paper that their experiments were also inadequate to decide between the existence or nonexistence of the linear effect.

\section{Other NBS Publications}

\section{J. Res. NBS 67B (Math. and Math. Phys.), No. 4 (Oct.}

\section{Dec. 1963) 75 cents.}

Zonal harmonic perturbations of an accurate reference orbit of an artificial satellite. J. P. Vinti.

Optimal periodic inspection programs for randomly failing equipment. G. H. Weiss.

An analysis of pedestrian queueing. G. H. Weiss.

Solutions of the equation $\Psi_{x x}+\frac{1}{x} \Psi_{x}+K x^{n} e^{\Psi}=0$, E. A. Kearsley. (See above abstract.)

On the graphs of finite idempotent Boolean relation matrices. D. Rosenblatt. (See above abstract.)

J. Res. NBS 68D (Radio Sci.), No. 1 (Jan. 1964) \$1.00.

Comparison of observed VLF attenuation rates and excitation factors with theory. A. D. Watt and R. D. Croghan.

Field Intensity measurements at $10.2 \mathrm{kc} / \mathrm{s}$ over reciprocal paths. J. C. Hanselman, C. J. Casselman, M. L. Tibbals, and J. E. Bickel.

The propagation of VLF waves over distances between 1000 and $3000 \mathrm{~km}$. B. Burgess.

Some experimental results concerning nonreciprocal eastwest VLF wave propagation. B. Burgess.

An experimental study of the phase stability of VLF signals. D E. Hampton.

Some particular observations on diurnal phase variations of VLF transmission received in Paris. B. Decaux and A. Gabry.

Periodic fading of VLF signals received over long paths during sunrise and sunset. D. D. Crombie.

Effects of wall perturbations in multimode waveguides. S. W. Maley and E. Bahar.

VLF Utilization at NASA satellite tracking stations. C. H. Looney, Jr.

Long wave associated with disturbances produced in plasmas. H. Bremmer. (See above abstract.)

Some remarks on the Watson transformation and mode theory. L. A. Berry.

Concerning limitations and further corrections to geometricoptical theory for LF/VLF propagation between the ionosphere and the ground. J. R. Johler. (See above abstract.)

Some remarks on mode and ray theories of VLF radio propagation. J. R. Wait.

Two-dimensional treatment of mode theory of the propagation of VLF radio waves. J. R. Wait.

Reflection of electromagnetic waves from a lossy magnetoplasma. J. R. Wait and L. C. Walters.

Propagation of ELF waves below an inhomogeneous anisotropic ionosphere. J. Galejs and R. V. Row.

VLF propagation under the ionosphere in the lowest mode of horizontal polarization. H. A. Wheeler.

Propagation of VLF waves under disturbed conditions. B. Burgess.

VLF disturbances caused by trapped beta-rays from the decay of neutrons produced in high-altitude nuclear explosions. A. J. Zmuda, B. W. Shaw, and C. R. Haave.

VLF anomalies observed at State College, Pa., during the U.S. 1962 high-altitude nuclear tests. C. F. Sechrist.

J. Res. 68D (Radio Sci.), No. 2 (Feb. 1964). \$1.00.

Generation of an electromagnetic pulse by an expanding plasma in a conducting half-space. A. P. Stogryn and R. N. Ghose.
Impedance of a monopole antenna with a radial-wire ground system on an imperfectly conducting half-space, part II. S. W. Maley and R. J. King

Capacitor type biconical antennas. J. Galejs.

Simulated angular response patterns for transhorizon propagation. J. W. Strohbehn and A. T. Waterman, Jr.

Radio-star scintillations from ionospheric waves. J. W. Warwick.

Ionosonde studies of some chemical releases in the ionosphere. J. W. Wright.

Diurnal changes and transmission time in the arctic propagation of VLF waves. W. T. Blackband.

Geometrical optics convergence coefficient for the whistler case. J. H. Crary.

Comments on a paper 'Collisional Detachment and the Formation of an Ionospheric' by E. T. Pierce. H. R. Arnold.

The quasi-longitudinal approximation in the generalized theory of radio wave absorption. R. F. Benson.

Diurnal phase variation of VLF waves at medium distances. H. Volland.

Application of diffractions by convex surfaces to irregular terrain situations. H. T. Dougherty and L. J. Maloney.

Effect of lossy earth on antenna gain. R. J. Coe and W. L. Curtis.

Propagation of radio waves with frequency $99.9 \mathrm{Mhz}$ as a function of the vertical structure of the atmosphere derived from daily radiosonde observations. G. P. A. Braam.

Bibliography of temperature measurement, July 1960 to December 1962, C. Halpern, NBS Mono. 27, Suppl. 1 (Sept. 13, 1963), 20 cents.

1963 Supplement Screw-thread standards for federal services, (Parts I, II, and III) Handb. H28 (1957) (Oct. 15, 1963), 70 cents

Clinical Dosimetry, Recommendations of the International Commission on Radiological Units and Measurements, NBS Handb. 87 (Aug. 9. 1963), 40 cents. (This publication supersedes parts of H78. Handbooks 84 through 89 will completely replace $\mathrm{H} 78$.)

Methods of evaluating radiological equipment and materials, Recommendations of the International Commission on Radiological Units and Measurements, NBS Handb. 89 (Aug. 23, 1963), 35 cents. (This publication supersedes parts of H78. Handbooks 84 through 89 will completely replace $\mathrm{H} 78$.)

Hydraulic research in the United States, 1963, NBS Misc. Publ. 249 (Aug. 9, 1963), \$1.00.

Mean electron density variations of the quiet ionosphere, No. 11 - January 1960, J. W. Wright, L. R. Wescott, and D. J. Brown, NBS Tech. Note 40-11 (Aug. 30, 1963), 40 cents.

Mutual interference between surface and satellite communication systems, W. J. Hartman and M. T. Decker, NBS Tech. Note 126 (Aug. 1, 1963), 35 cents.

Antenna beam elevation angle for control of tropospheric interference between space system earth terminals and terrestrial stations, S. G. Lutz and W. J. Hartman, NBS Tech. Note 180 (Aug. 25, 1963), 15 cents.

Computer program for ionospheric mapping by numerical methods, M. E. Hinds and W. B. Jones, NBS Tech. Note 181 (Aug. 20, 1963), 50 cents.

A note on antipodal focussing, J. R. Wait, NBS Tech. Note 182 (Aug. 20, 1963), 15 cents.

Report on technical investigation of odometers, D. R. Mackay, NBS Tech. Note 195 (Aug 6, 1963), 25 cents.

Synthesis of perfluorostyrene and (2,2-difluorovinyl)perfluorobenzene ( $\alpha$-hydroheptafluorostyrene). A general method for synthesis of highly fluorinated styrenes, J. M. Antonucci and L. A. Wall, SPE Trans. 3, No. 3, 225-230 (July 1963).

Radiation transfer problems in the rocket ultra-violet lines, C. Pecker and R. N. Thomas, J. Quant. Spectry. Radiative Transfer 3, No. 2, 163-165 (June 1963).

Stress-corrosion cracking of type 304 stainless steel at 455 to 615 F, H. L. Logan, M. J. McBee, and M. Romanoff, Mater. Res. Std. 3, No. 8, 635-639 (Aug. 1963). 
Lines of constant correlated color temperature based on MacAdam's (u,v) uniform ehromaticity transformation of the CIE diagram, K. L. Kelly, J. Opt. Soc. Am. 53, No. 8, 999-1002 (Aug. 1963).

Intrinsic attenuation, R. W. Beatty, IEEE Trans. Microwave Theory Tech. MTT-11, No. 3, pp. 179-182 (May 1963).

A note on modular groups, M. Newman, Proc. Am. Math. Soc. 14, No. 1, 124-125 (Feb. 1963).

Leaf temperature and energy exchange, D. M. Gates, Archiv Meteorol. Geophys. Bioklimatol. Ser. B, 12, 321-336 (1963).

Equatorial ionospheric variations during geomagnetic storms, S. Matsushita, J. Geophys. Res. 68, 2595-2601 (May 1, 1963).

The calibration of inductive voltage dividers, T. L. Zapf, ISA Proc. 1962, 1z,pt. I, pp. $10.2 .62-1$ to $10.2 .62-8$ (1962).

Effects of the nuclear explosion over Johnston Island observed in Peru on July 9, 1962, M. Casaverde, A. Giesecke, and R. Cohen, J. Geophys. Res. 68, No. 9, 2603-2611 (May 1, 1963).

Derivation of electron density profiles in the lower ionosphere using radio absorption measurements at multiple frequencies, R. Parthasarathy, G. M. Lerfald, and C. G. Little, J. Geophys. Res. 68, 3581-3588 (June 15, 1963).

Radiolysis of methane, P. J. Ausloos and S. G. Lias, J. Chem. Phys. 38, No. 9, 2207-2214 (May 1, 1963).

The stress-corrosion cracking of type 304 stainless steel at 455 to 615 F, H. L. Logan, M. J. McBee, and M. Romanoff, Mater. Res. Std. 3, No. 8, 625-639 (Aug. 1963).

The redefinition of the second and the velocity of light, G. E. Hudson and W. Atkinson, Physies Today 16, No. 5, 30-36 (May 1963).

Thermal conductivity, R. L. Powell, American Institute of Physies Handb. 2d Ed. pp. 4-76-4-101 (MeGraw-Hill Book Co., Inc., New York, N.Y., 1963).

Digital pattern recognition by moments, F. L. Alt, Book, Optical Character Recognition, Ed. G. L. Fischer, D. K. Pollack, B. Raddick, and M. E. Stevens pt. II, pp. 153-179 (Spartan Books, Washington, D.C., 1962).

D-gluco-L-glycero-3-octulose, a crystalline ketose from Derythrose, R. Schaffer and A. Cohen, J. Organ. Chem. 28, 1929-1930 (1963).

A phenomenological theory of overvoltage for metallic particles, J. R. Wait. Book, Overvoltage Research and Geophysical Applications, Ed. J. R. Wait, ch. 3, p. 22 (Pergamon Press, Inc., New York, N.Y., 1959).

Statistics in chemical analysis, W. J. Youden, Handbook of Analytical Chemistry, Sec. 14, pp. 14-1-14-9 (McGrawHill Book Co., Inc., New York, N.Y., 1963).

Radiation, L. S. Taylor, Americana Annual 620-622 (Americana Corporation, Chicago, Ill., 1961).

Ten year weathering data on aluminum alloys, W. H. Ailor, Jr., and F. M. Reinhart, Materials Protect. 2, No. 6, 30-36 (June 1963).

Modulary groups of $t \times t$ matrices, M. Newman and J. R. Smart, Duke Math. J. 30, 253-257 (1963).

An experimental method of estimating $\dot{F}$-region collision frequencies (research note), J. K. Hargreaves, J. Atmospheric and Terrest. Phys. 25, 300-304 (May 1963).

Optical Character Recognition, Ed., G. L. Fischer, D. K. Pollack, B. Raddick, and M. E. Stevens (Spartan Books, Washington, D.C. 1962).

Achievement of measurement of agreement among electrical standards laboratories, F. D. Weaver, Instr. Control Systems 36, 128-131 (July 1963).

A $\mathrm{He}^{3}$ cryostat for performing experiments with oriented nuclei, E. Ambler, R. Dove, and R. Kaeser (Proc. 1962 Cryogenic Engineering Conf.), Book, Advances in Cryogenic Engineering 8, Sec. H-2, 443-554 (Plenum Press Inc., New York, N.Y., 1963).

Spectroscopic absorption of NO in crystalline and liquid krypton, G. L. Pollack and H. P. Broida, J. Chem. Phys. 38, No. 8, 2012-2015 (Apr. 15, 1963).

The possibility of guided electromagnetic waves in the earth's crust, J. R. Wait, IEEE Trans. Ant. Prop. AP-11, 330-335 (May 1963).

The nature of the compound obtained from aqueous cesium chloride solution and hydrogen chloride, A. G. Maki and and R. West, Inorganic Chem. 2, 657 (1963).
Laboratory investigation of overvoltage, L. S. Collett, A. A. Brant, W. E. Bell, K. A. Ruddock, H. O. Siegel, and J. R. Wait, Book, Overvoltage Research and Geophysical Applications, Ed. J. R. Wait, ch. 5, p. 50 (Pergamon Press, Inc., New York, N.Y., 1959).

1,2,2-trifluorovinyl phenyl ether and 2,3,4,5,6-pentafluorophenyl 1,2,2-trifluorovinyl ether and their polymers, W. J. Pummer and L. A. Wall, SPE Trans. 3, No. 3, 220-224 (July 1963).

Radiometry, M. M. Reynolds, R. J. Corruccini, M. M. Fulk, and R. M. Burley, American Institute of Physies Handb. 2d ed., pp. 6-153-6-172 (McGraw-Hill Book Co., Inc., New York, N.Y., 1963).

Classification of resonances in the electron scattering cross section of $\mathrm{Ne}$ and $\mathrm{He}$, J. A. Simpson and U. Fano, Phys. Rev. Letters 11, 158 (1963).

Bolometric microwave power calibration techniques at NBS, R. F. Desch and R. E. Larson, Proc. ISA 17th Annual Instrument-Automation Conf. \& Exhibit (Oct. 1962).

Criteria from the transient decay curves, J. R. Wait and L. S. Collett, Book, Overvoltage Research and Geophysical Applications, Ed. J. R. Wait, ch. 6a, p. 71 (Pergamon Press, Inc., New York, N.Y., 1959).

On the interpretation of prominence spectra. VI. Temperature determination and a model for quiescent prominences, J. T. Jefferies and F. Q. Orrall, Astrophys. J. 13\%, 1232-1241 (May 15, 1963).

The lifetime and movement of artificially produced electron clouds observed with spaced ionosondes, J. W. Wright, J. Geophys. Res. 68, No. 10, 3011-3020 (May 15, 1963).

Isopiestic vapor pressure measurements of the tenary system: Sorbitol-sodium chloride-water at $25^{\circ}, \mathrm{V}$. E. Bower and R. A. Robinson, J. Phys. Chem. 6\%, 1540-1541 (1963).

The intermediate state of some hard superconductors, V. Arp, R. H. Kropschot, and T. S. Craig, Book, Superconductors, pp. 135-141 (Interscience Publ., New York, N.Y., 1962)

Ferromagnetic resonance and shape dependent effects, L. A. Steinert, J. Appl. Phys. Letter 34, 2106-2107 (July 1963).

Characteristics of spread $F$ at high geomagnetic latitude, W. K. Klemperer, J. Geophys. Res. 68, No. 10, 3191-3196 (May 15, 1963).

The thermodynamies of the ternary system: Urea-sodium chloride-water at $25^{\circ}$, V. E. Bower and R. A. Robinson, J. Phys. Chem. 67, 1524-1527 (1963).

Verification of the tenfold assignment of the Baryon resonances, S. Meshkov, C. A. Levinson, and H. J. Lipkin, Phys. Rev. Letters 10, No. 8, 361-364 (Apr. 15, 1963).

Vapor snakes in solid argon, G. L. Pollack and H. P. Broida, J. Chem. Phys. 38, No. 4, 968-969 (Feb. 15, 1963).

The day-to-night ratio of cosmic noise absorption during polar cap absorption events, C. S. Gilmor, J. Atmospheric Terrest. Phys. 25, 263-266 (May 1963).

Photographic dosimetry, megaroentgen range, W. L. McLaughlin, Encyclopaedia of X-rays and Gamma Rays, Ed. G. L. Clark, pp. 307-309 (Reinhold Publ. Corp., New York, N.Y., 1963.)

Proposed experiment to measure effects of ground roughness on the dose rate from fallout radiation, C. Eisenhauer, Health Phys. 9, 503-506 (1963).

Standards for dental radiographic film, G. C. Paffenbarger, Mag. Std. 34, 148 (May 1963).

The variable-frequency method, J. R. Wait, Book, Overvoltage Research and Geophysical Applications, Ed. J. R. Wait, ch. 4, p. 29 (Pergamon Press, Inc., New York, N.Y., 1959).

Heat transfer between a cryo-surface and a controlled atmosphere, Suppl. Bull. Intern. Inst. Refrigeration Annexe $1962-1$, p. 89 (Aug. 1962).

Polymers and telomers of 4-chloroperfluoroheptadiene-1,6, J. E. Fearn and L. A. Wall, SPE Trans. 3, No. 3, 231-234 (July 1963).

Excitation of pi-electrons in polystyrene and similar polymers by 20 Kev electrons, N. Swanson and C. J. Powell, J. Chem. Phys. 39, 630-634 (Aug. 1, 1963).

Cane sugar refining. II. Decolorization with adsorbents, V. R. Deitz and F. G. Carpenter, Cane Sugar Handb. Ed, 
G. P. Meade, 9th edition, pp. 342-385 (John Wiley \& Sons Inc., New York, N.Y., Aug. 1963).

Klystron protection circuit, W. E. Case and N. T. Larsen, Rev. Sci. Instr. 34, No. 7, 809-810 (July 1963).

Stable $6300 \AA$ auroral ares in mid-latitudes, F. E. Roach and J. R. Roach, Planetary Space Sci. 11, 523-545 (1963).

Parable of the Fisherman, W. J. Youden, Phys. Teacher Editoria! 1, No. 3, 120-121 (Sept. 1963).

The wear of magnetic recording tape and solubility of the binder, F. Nesh, IEEE Trans. Audio AU-11, No. 3, 97 (May-June 1963).

Special techniques for use in sugar analysis, V. R. Deitz and F. G. Carpenter, Cane Sugar Handb. Ed. G. P. Meade, 9th edition, pp. 605-619 (John Wiley \& Sons, Inc., New York, N.Y., Aug. 1963).

Humidity (measurement of moisture in gas), A. Wexler, ISA Transducer Compendium, pp. 502-508 (Sept. 1963).

Convection phenomena from plants in still air, D. M. Gates and C. M. Benedict, Am. J. Botony 50, 563-573 (July 1963).

Triboluminescence in a inercury bubbler, L. Schoen, Can. J. Phys. 38, 967-970 (1960).

Deuterium isotope effect on glass transformation temperatures of aqueous inorganic solutions, L. C. Shepley and A. B. Bestul, J. Chem. Phys. 39, No. 3, 680-687 (Aug. 1, 1963).

Mechanical reading of characters and recognition, M. E Stevens (Proc. Intern. Patent Office Workshop on Information Retrieval), 125th Anniversary of the U.S. Patent Act of 1836 , pt. II, p. 205 (1962).

One year trial for new voltmeter standard, C. Stansbury, Mag. Std. 34, No. 3, 240-241 (Aug. 1963).

Pressure-density-temperature relations of freezing liquid parahydrogen to 350 atmospheres, Cryogenics 3, No. 1, 12-15 (Mar. 1, 1963).

Status of sugar color and turbidity measurements, F. G. Carpenter and V. R. Deitz, Am. Soc. Sugar Beet Technologists 12, No. 4, 326-347 (Jan. 1963).

Portable 2 flow counter for the detection of $\alpha$ and $\beta$ particles in smear samples, L. Costrell, A. Schwebel, and G. W. Zimmer, Health Phys. 9, No. 6, 643 (June 1963).

The occurrence of short-duration cosmic noise absorption events inside the southern auroral zone, C. S. Gillmor, Jr., and J. K. Hargreaves, J. Atmospheric and Terrest. Phys. 25, 311-317 (June 1963).

An unmodulated twin channel microwave attenuation measurement system, D. H. Russell, ISA 18th Annual Conf., pp. 1-17 (Sept. 1963).

Application of distillation techniques to radiochemical separations, J. R. DeVoe, Natl. Acad. Sci.-Natl. Res. Council Nuclear Science Series, Radiochemical Tecbniques NASNS3108 (Aug. 1962).

Physical measurements and experiment design, W. J. Youden (Colloq. Intern. Centre Natl. Recherche Sci., Aug.-Sept. 1961), Book, Le Plan d'Experiences, No. 110, p. 115 (Centre National de la Recherche Scientifique, Paris, France, 1963).
Airglow research, F. E. Roach, Trans. Am. Geophys. Union 44, No. 2, 431-432 (June 1963).

The National Bureau of Standards reactor facility, C. O. Muehlhause, Capital Chemist 12, No. 1, 7-10 (Jan. 1962).

Determination of rhodium in rhodium-uranium alloys by precipitation with hydrogen sulfide, E. J. Maienthal, Anal. Chem. 35, 1094-1095 (July 1963).

Determination if bitumen content in expansion joint fillers, E. Horowitz and J. Mandel, Mater. Res. Std. 3, No. 9, 723-725 (Sept. 1963).

Time and frequency broadcasting, A. H. Morgan, ISA J. 10, No. 6, 49-54 (June 1963).

Distillation, A. T. Leslie and E. C. Kuehner, Analytical Chemistry Handb. XIII, Methods of Separation, Ed. L. Meites, Sect. 10, pp. 10-23-10-42 (1963).

Precision and accuracy in electromagnetic measurements, R. D. Huntoon (Intern. Conf. Precision Electromagnetic Measurements, Boulder, Colo., Aug. 14-17, 1962), IRE Trans. Instr. I-11, Nos. 3 and 4, 84 (Dec. 1962).

Quadrupole coupling constants from the microwave spectrum of hydrazoic acid, R. A. Forman and D. R. Lide, Jr., J. Chem. Phys. 39, No. 4, 1133-1134 (Aug. 15, 1963).

The following papers were published in Ionospheric Sporadic E, Ed. E. K. Smith and S. Matsushita (Pergamon Press, Inc., New York, N.Y., 1962).

A note on the heights of the different IGY types of $E_{\mathrm{s}}, \mathrm{S}$. C. Gladden, pp. 178-181.

A study of radio wave scattering from sporadic $E$ near the magnetic equator, K. L. Bowles and R. Cohen, pp. 51-77.

A theoretical study of sporadic- $E$ structure in the light of radio measurements, K. Tao, pp. $235-257$.

Lunar tidal variations of sporadic $E$, S. Matsushita, pp. $194-214$.

On the width of the equatorial $E_{s}$ belt, R. W. Knecht and R. E. McDuffie, pp. 215-218.

Recent sporadic- $\boldsymbol{E}$ experimental work in the United States, J. F. DeGregorio, J. W. Finney, K. Kildahl, and E. K. Smith, pp. 141-142.

Sporadic- $E$ propagation with $3 \mu$ sec pulses, G. R. Ochs, R. J. Carpenter, and E. K. Smith, pp. 143-148.

The night- $E$ layer, G. A. M. King, pp. 219-231.

The occurrence of sporadic E, E. K. Smith, pp. 3-12.

The occurrence of sporadic $E$ during the IGY, H. I. Leighton, A. H. Shapley, and E. K. Smith, pp. 166-177.

Variations in frequency of occurrence of sporadic $E, 1949$ 1959, W. B. Chadwick, pp. 182-193.

*Publications for which a price is indicated are available by purchase from the Superintendent of Documents, Government Printing Office, Washington, D.C., 20402 (foreign postage, onefourth additional). Reprints from outside journals and the NBS Journal of Research may often be obtained directly from the authors. 